\title{
Assessment of Lignocellulosic Biomass Using Analytical Spectroscopy: an Evolution to High-Throughput Techniques
}

\author{
Jason S. Lupoi • Seema Singh • Blake A. Simmons • \\ Robert J. Henry \\ Published online: 2 July 2013 \\ (C) The Author(s) 2013. This article is published with open access at Springerlink.com
}

\begin{abstract}
Lignocellulosic biomass has been proposed as an option for reducing global dependence on nonrenewable energy sources, such as oil. Selection and development of biomass feedstocks that efficiently yield the maximum fuel or biomaterial requires the availability of reliable methods for compositional and structural characterization of plant material. Many standard methods for biomass analysis are laborious and slow, and employ a variety of harsh reagents requiring some degree of remediation. The use of simpler and more rapid spectroscopic methods has proved invaluable in analyzing biomass. In the twenty-first century, researchers have employed techniques such as Raman, mid-infrared, and near-infrared spectroscopy for a wide range of applications in endeavors to further understand biofuel feedstocks. While many methods remain time consuming and expensive, a growing interest in high-throughput spectroscopic techniques has provided faster and larger scale feedstock screening for desirable traits. This review seeks to provide an overview of
\end{abstract}

J. S. Lupoi • B. A. Simmons · R. J. Henry

Queensland Alliance for Agriculture and Food Innovation,

The University of Queensland, St. Lucia, Brisbane, QLD,

Australia 4072

B. A. Simmons

e-mail: basimmons@lbl.gov

R. J. Henry

e-mail: robert.henry@uq.edu.au

J. S. Lupoi $(\varangle) \cdot$ S. Singh $\cdot$ B. A. Simmons

Joint BioEnergy Institute, Lawrence Berkeley National Laboratory,

5885 Hollis Street, Emeryville, CA 94608, USA

e-mail: jslupoi@lbl.gov

S. Singh

e-mail: seesing@sandia.gov

S. Singh $\cdot$ B. A. Simmons

Biological and Materials Science Center, Sandia National

Laboratories, 7011 East Avenue, Livermore, CA 94551, USA both high-throughput techniques and those requiring longer analysis times but still providing abundant qualitative and quantitative data. While applications of these instrumental methods have been researched for decades, more recent developments will be discussed here.

Keywords Biomass - Spectroscopy $\cdot$ Raman spectroscopy . Near-infrared spectroscopy $\cdot$ Fourier transform infrared spectroscopy $\cdot$ High-throughput $\cdot$ Chemometrics

\section{Background}

The conversion of lignocellulosic biomass to diverse fuel sources is considered one possible solution to supplant world dependence on fossil fuels due to abundant biopolymers, cellulose, and lignin. Perlack et al., in a 2011 update to the 2005 US Department of Energy Billion Ton Report, estimated that the available biomass from agricultural and forest crops including wastes plus dedicated energy feedstocks, in the US, is between 400 and 600 million tons at a cost of $\$ 60$ per dry ton or less $[1,2]$. To eliminate the fuel versus food dichotomy, the use of first generation crops such as corn has declined, while research on second generation feedstocks such as poplar, switchgrass, Miscanthus, and eucalypts (e.g., Eucalyptus, Corymbia) has expanded [1-8]. The National Academy of Science predicts available cellulosic biomass by 2020 to be 548 million tons without impact on food production [9]. Before plants can be deemed suitable for biofuels, they must be structurally and compositionally characterized such that feedstocks can be selectively screened for the presence of quintessential fuel-producing traits. Less ideal energy-dedicated crops can be genetically tailored to contain these key attributes, such as high cellulose and low or easily degradable lignin contents $[2-4,10]$.

High-throughput screening techniques are necessary such that vast quantities of raw and genetically tailored feedstocks 
can be assessed both at the research and development stage and in later routine commercial production and processing. Current wet chemical techniques for studying biomass composition are laborious and generally require harsh reagents such as acetyl bromide [11-13], sulfuric acid [14-20], trifluoroacetic acid $[16,21,22]$, boron trifluoride etherate in thioacidolysis [23, 24], and nitrobenzene [11, 25]. Analytical techniques such as high-performance liquid chromatography (HPLC) [17, 19, 20, 26-32], gas chromatography(GC) or GC/mass spectrometry (GCMS) [33-39], pyrolysis (pyro) GCMS/molecular beam (MB) MS [40-51], thermogravimetric analysis [52-54], and nuclear magnetic resonance (NMR) [34, 55-104] require tedious sample preparations, long analysis times, and/or can destroy the sample in the analytical process. Chemometrics has alleviated some of these obstacles through the marriage of standard analytical techniques with spectral data from high-throughput, spectroscopic instrumentation [105-109]. After performing the standard technique once, future sample parameters can be predicted by inserting spectral data into robust calibration models. For example, by rapidly predicting the chemical composition of feedstocks, pretreatment and saccharification methods can be tailored to ensure efficient hydrolysis. Analytical techniques capable of monitoring online structural changes during biomass pretreatments or rapidly quantifying hydrolysis and fermentation products such as glucose and ethanol are required in production management. Applications of high-throughput, non-spectroscopic methods have also been developed [14, 26, $27,30,41,47,48,110-112]$. Table 1 provides a guide for reference and spectroscopic techniques used in analyzing biomass, while Table 2 depicts some of the key advantages and disadvantages encountered when selecting appropriate analytical methods.

The use of spectroscopy can provide noninvasive, highthroughput, techniques requiring little to no sample preparation and qualitative and quantitative data from on- or offline processes. The development of instrumentation utilizing fiber optics has enabled advances in portable and process chemical applications [113-118]. The focus of this review is to provide a sampling of recent, spectroscopic methods for studying lignocellulosic biomass. Although applications of common spectroscopic instrumentation such as NMR are discussed, the emphasis will be on methods with highthroughput capabilities. For a detailed analysis of spectroscopic fundamentals and instrumentation, the reader is referred to various informative resources $[80,105,108,113$, $116,117,119-131]$.

\section{Raman Spectroscopy}

When an analyte is measured spectroscopically, light interacting with the sample can be absorbed, transmitted, or scattered.
Raman spectroscopy measures the light scattered from a molecule when irradiated with a light source, commonly a laser [124, 128]. When the laser interacts with the sample, the electron cloud is perturbed and excites the molecule to a short-lived "virtual state" as there is insufficient energy to promote the molecule to a higher energy level. If the energy of scattered photons differs from incident photons, an energy transfer has occurred, leading to Raman scattering, an inherently weak process, resulting for about 1 in every $1-100$ million photons. Nonetheless, Raman spectroscopy is nondestructive, requires little to no sample preparation, provides high spectral resolution, is not inhibited by the presence of water in samples, offers field portability, and can provide abundant qualitative and quantitative information. A key experimental parameter when developing Raman applications is the selection of excitation wavelength. Many compounds in biomass exhibit significant and detrimental spectral contributions from laser-induced fluorescence, which can often obscure analyte signal. To combat fluorescence interference, the use of near-infrared (NIR) wavelengths is often employed. Applications of Raman spectroscopy to biomass have previously been reviewed [119, 131, 132].

\section{Fourier Transform Raman Spectroscopy}

The use of Raman spectroscopy for studying lignocellulosic biomass has become widespread in the literature, with the majority of research exploring the applicability of Fourier transform (FT) Raman spectroscopy for woody feedstock analysis [97, 119, 132-164]. Agarwal and coauthors have developed FT-Raman spectroscopy for a variety of applications [119, 132-143]. Milled wood lignin (MWL) from black spruce, loblolly pine, sweetgum, and aspen were analyzed, and band assignments were determined for each analyte [137]. The authors found that band positions were similar between the hardand softwoods, although the softwood spectra revealed unique peaks at 384,557 , and $1,298 \mathrm{~cm}^{-1}$, while peaks at 417,431 , $447,472,503,522,597$, and $1,156 \mathrm{~cm}^{-1}$ were present solely in hardwoods. The $2,940-\mathrm{cm}^{-1}$ vibrational mode characteristic of aliphatic $\mathrm{C}-\mathrm{H}$ bonds was more intense in hardwoods due to a higher degree of aromatic methoxy groups from syringyl moieties. In the most intense region of lignin spectra, peaks near 1,662 and $1,621 \mathrm{~cm}^{-1}$ were assigned to $\mathrm{C}=\mathrm{C}$ bonds in coniferyl alcohol and $\mathrm{C}=\mathrm{O}$ bonds in coniferaldehyde, and ringconjugated $\mathrm{C}=\mathrm{C}$ bonds in coniferaldehyde, respectively. Hardwoods would, likewise, have signal generated from sinapyl alcohol and sinapaldehyde. The MWLs were subjected to various chemical treatments (alkaline bleaching, diimide hydrogenation, acetylation, and methylation), and the spectra were compared to investigate treatment-induced structural changes. Lignin was also quantified using the ratio of the lignin $1,600 \mathrm{~cm}^{-1}$ /cellulose $1,096 \mathrm{~cm}^{-1}$ bands and calibrated to both Klason $\left(R^{2}=0.967\right)$ and total $\left(R^{2}=0.945\right)$ lignin contents obtained from wet chemical techniques $[134,143]$. Chundawat 
Table 1 Standard and spectroscopic methods for biomass analysis

\begin{tabular}{|c|c|c|c|}
\hline Biomass component & Reference methods & Spectroscopic methods & Rapid methods \\
\hline \multicolumn{4}{|l|}{ Carbohydrates } \\
\hline Total carbohydrates & $\begin{array}{l}\text { Phenol-sulfuric acid [15] } \\
\text { Trifluoroacetic acid [21] } \\
\text { Van Soest [264] }\end{array}$ & & $\begin{array}{l}\text { PyroMBMS }[41,47,48,50] \\
\text { LC [14, 111] } \\
\text { FT-Raman }[149,153] \\
\text { FTIR [218] } \\
\text { NIR [29, 41, 221, 227, 229-231, 234, } \\
\quad 236-238,240,242,247,249-251] \\
\text { TGA [52-54] } \\
\text { UV-VIS [22, 263] }\end{array}$ \\
\hline Cellulose content & $\begin{array}{l}\text { Updegraff [265] } \\
\text { Monoethanolamine [266] } \\
\text { Acid hydrolysis-LC [20,28] } \\
\text { Van Soest [264] }\end{array}$ & $\begin{array}{l}\text { FTIR [174-176] } \\
\text { NMR [57] }\end{array}$ & $\begin{array}{l}\text { PyroMBMS }[41,47,48,50] \\
\text { LC [14, 111] } \\
\text { FT-Raman [149, 153] } \\
\text { FTIR [206, 217] } \\
\text { NIR [29, 41, 221, 227, 229-231, 234, } \\
\quad 236-238,240,242,246,247,249-251] \\
\text { Raman Imaging [191-196] } \\
\text { TGA [52-54] } \\
\text { UV-VIS [22, 26, 263] }\end{array}$ \\
\hline Cellulose crystallinity & XRD [91] & $\begin{array}{l}\text { NMR }[66,77,79,88] \\
\text { FT-Raman }[144]\end{array}$ & FT-Raman [122, 124, 138, 139] \\
\hline $\begin{array}{l}\text { Non-cellulosic } \\
\text { polysaccharide } \\
\text { content }\end{array}$ & $\begin{array}{l}\text { Ethanol extraction [253] } \\
\text { Van Soest [264] } \\
\text { Acid hydrolysis-LC [20] }\end{array}$ & & $\begin{array}{l}\text { LC }[14,111] \\
\text { PyroMBMS [47] } \\
\text { FT-Raman }[149,150,153] \\
\text { FTIR }[195,200] \\
\text { NIR }[29,41,221,233,234,242,247, \\
\quad 249-251] \\
\text { TGA [52-54] }\end{array}$ \\
\hline $\begin{array}{l}\text { Monosaccharide } \\
\text { content }\end{array}$ & $\begin{array}{l}\text { Acid hydrolysis-LC [20] } \\
\text { GC [33] }\end{array}$ & & $\begin{array}{l}\text { PyroMBMS [41] } \\
\text { FT-Raman }[149,153] \\
\text { FTIR [190, 200, 202] } \\
\text { NIR [29, 41, 235, 245, 247, 249, 251] } \\
\text { TGA [52-54] }\end{array}$ \\
\hline $\begin{array}{l}\text { Structural analysis of } \\
\text { polysaccharides }\end{array}$ & Methylation GCMS [35] & $\begin{array}{l}\text { FTIR }[62,72,78,154,175,184,197, \\
\quad 213,214] \\
\text { FT-Raman }[97,132,133,138,144,145, \\
\quad 154] \\
\text { Dispersive Raman }[73,177,213] \\
\text { NMR }[34,55,72,91,99-101] \\
\text { Fluorescence }[214,256]\end{array}$ & Raman Imaging [191-195] \\
\hline \multicolumn{4}{|l|}{ Lignin } \\
\hline Total lignin content & $\begin{array}{l}\text { Klason analysis [267] } \\
\text { Acetyl bromide [13] } \\
\text { Van Soest [264] }\end{array}$ & $\begin{array}{l}\text { FTIR }[174-176] \\
\text { UV-Raman }[190] \\
\text { UV-VIS }[11,19,20,22,63,89,181,268] \\
\text { NMR }[57,59,60]\end{array}$ & $\begin{array}{l}\text { PyroMBMS [41, 47, 48] } \\
\text { LC [14] } \\
\text { FT-Raman [134, 143, 149, 153] } \\
\text { FTIR [206, 217, 218] } \\
\text { NIR [29, 41, 221, 224, 227, 229, 231, 234, } \\
\quad 236-238,240-242,245-247,249-253] \\
\text { Raman Imaging [191-195] } \\
\text { TGA [52-54] } \\
\text { UV-VIS [208, 269] } \\
\text { Fluorescence [236, 237] }\end{array}$ \\
\hline
\end{tabular}


Table 1 (continued)

\begin{tabular}{|c|c|c|c|}
\hline Biomass component & Reference methods & Spectroscopic methods & Rapid methods \\
\hline \multirow[t]{4}{*}{$\mathrm{S} / \mathrm{G} / \mathrm{H}$ content } & Acidolysis $[270,271]$ & UV-Raman $[182,183]$ & PyroMBMS [47] \\
\hline & Thioacidolysis $[23,24]$ & NMR $[63,83,94]$ & FT-Raman $[148,161,162]$ \\
\hline & Nitrobenzene [25] & FTIR [51] & Dispersive Raman [73] \\
\hline & $\begin{array}{l}\text { Cupric oxide }[25,272] \\
\text { PyroGCMS }[44,51,64,84,85]\end{array}$ & & NIR [24, 222, 246] \\
\hline \multirow[t]{6}{*}{ Structural analysis } & $\begin{array}{l}\text { Functionality specific } \\
\text { reactions }[273-277]\end{array}$ & $\begin{array}{l}\text { FTIR }[61,62,67,69,78,89,154,175 \\
\quad 176,184,202,204,210,214]\end{array}$ & FT-Raman [164] \\
\hline & PyroGC [65] & $\begin{array}{l}\text { FT-Raman }[97,119,132,133,137,139, \\
\quad 146,164]\end{array}$ & FTIR [208] \\
\hline & & $\begin{array}{l}\text { Dispersive Raman }[73,171,174-176] \\
\text { RR [178-181] }\end{array}$ & Raman Imaging [191-195] \\
\hline & & UV-Raman [78, 181-184, 187, 189] & \\
\hline & & $\begin{array}{l}\text { NMR }[34,56,58,61-65,67-71,75,78, \\
\quad 83-87,89,92-104]\end{array}$ & \\
\hline & & Fluorescence [204, 214, 255, 258] & \\
\hline \multirow{5}{*}{$\begin{array}{l}\text { Hydroxycinnamic } \\
\text { acid linkages }\end{array}$} & $\mathrm{LC}[31,278]$ & NMR $[56,64,75,81,82,84-87,89]$ & \\
\hline & $\mathrm{DRFC} / \mathrm{GC}[37]$ & & \\
\hline & $\begin{array}{l}\text { Permanganate Oxidation/ } \\
\text { GCMS [65] }\end{array}$ & & \\
\hline & $\mathrm{GC}[36]$ & & \\
\hline & PyroGC $[42,49,51]$ & & \\
\hline \multicolumn{4}{|l|}{ Products } \\
\hline \multirow[t]{5}{*}{ Glucose } & $\mathrm{LC}[32]$ & Dispersive Raman $[172,173]$ & $\mathrm{LC}[27,30,110]$ \\
\hline & & UV-VIS [279] & FT Raman [160] \\
\hline & & & FTIR [211] \\
\hline & & & NIR $[225,235]$ \\
\hline & & & UV-VIS [26] \\
\hline \multirow[t]{3}{*}{ Ethanol } & GC, GCMS $[39,173]$ & Dispersive Raman [173] & FTIR [160] \\
\hline & & & FT-Raman [160] \\
\hline & & & NIR [225] \\
\hline \multicolumn{4}{|l|}{ Other } \\
\hline \multirow[t]{4}{*}{ Extractive content } & Polarity-based extractions & UV-Raman $[185,186]$ & NIR [224, 240, 241, 246, 247, 249] \\
\hline & {$[20]$} & & FT-Raman $[149,153]$ \\
\hline & & & FTIR $[206,218]$ \\
\hline & & & PyroMBMS [50] \\
\hline Protein content & Nitrogen [20] & & NIR [242] \\
\hline \multirow[t]{3}{*}{ Inorganic content } & Oven drying [20] & & NIR $[29,231,234,242,247,249,251]$ \\
\hline & Van Soest [264] & & Fluorescence $[236,237]$ \\
\hline & & & PyroMBMS $[48,50]$ \\
\hline
\end{tabular}

et al. used FT-Raman spectroscopy to gauge lignin removal during ammonia fiber explosion (AFEX) pretreatment of corn stover [97]. Lignin peaks $\left(1,600\right.$ and $\left.1,635 \mathrm{~cm}^{-1}\right)$ were about three times higher in the control compared to treated samples. The authors also noted that residual lignin had less ferulate and $p$-coumarate moieties through analysis of the $1,170 \mathrm{~cm}^{-1}$ cinnamoyl ester band.

FT-Raman spectroscopy was used to explore the phenomenon known as "self-absorption," which refers to the absorption of scattered photons by the analyte, leading to decreases in spectral intensities [136]. The 2,895- $\mathrm{cm}^{-1} \mathrm{C}-\mathrm{H}$ stretching region was most affected by self-adsorption, and the authors established that cellulose, not lignin, was the cause. A previous study had determined this peak to specifically be from cellulose [138]. In addition, the most intense lignin peak did not change in intensity. Spectral suppression, or reduction in peak intensity, was further determined to result from hydroxyl groups in polysaccharides and water.

The calculation of cellulose crystallinity index (CrI) by a variety of techniques has led to widely ranging indices 
Table 2 Advantages and disadvantages of analytical techniques for biomass characterization

\begin{tabular}{|c|c|c|}
\hline Technique & Advantages & Disadvantages \\
\hline \multirow[t]{3}{*}{ Fluorescence spectroscopy } & $\begin{array}{l}\text { - Lower cost, simple instrumentation }[126,236] \\
\text { - More selective than absorbance }[125]\end{array}$ & \multirow{3}{*}{$\begin{array}{l}\text { - Requires molecule to have fluorophore, } \\
\text { whether intrinsically or through labeling } \\
\text { [236] }\end{array}$} \\
\hline & $\begin{array}{l}\text { - } 2-3 \text { orders of magnitude more sensitive than UV-VIS } \\
\text { absorbance analysis [125] }\end{array}$ & \\
\hline & • Nondestructive $[236,237]$ & \\
\hline \multirow[t]{3}{*}{ FTIR spectroscopy } & $\begin{array}{l}\text { - More intense spectra generated than in Raman } \\
\text { spectroscopy; fundamental vibrations }[124,128]\end{array}$ & $\begin{array}{l}\text { - Spectra are very sensitive to presence of } \\
\text { water }[124,128]\end{array}$ \\
\hline & $\begin{array}{l}\text { - Complimentary to Raman spectroscopy }[124,128] \\
\text { - High-throughput capabilities }[206,217,218]\end{array}$ & \multirow[t]{2}{*}{$\begin{array}{l}\text { - May require specific sample preparation } \\
\text { such as with } \mathrm{KBr}[119]\end{array}$} \\
\hline & • Nondestructive $[131,211]$ & \\
\hline \multirow[t]{4}{*}{ NIR spectroscopy } & - Lower cost, simple instrumentation $[122,129,254]$ & $\begin{array}{l}\text { - Spectra are less intense those from FTIR } \\
\text { analysis [113] }\end{array}$ \\
\hline & - Little to no sample preparation required [254] & $\begin{array}{l}\text { - Only } \mathrm{C}-\mathrm{H}, \mathrm{O}-\mathrm{H}, \mathrm{N}-\mathrm{H} \text {, and } \mathrm{S}-\mathrm{H} \text { moieties } \\
\text { measured [122] }\end{array}$ \\
\hline & - Water compatible [124] & $\begin{array}{l}\text { - Requires deconvolution, often with } \\
\text { chemometrics }[108,113,254]\end{array}$ \\
\hline & • Field-portable [113] & • Calibration [113] \\
\hline
\end{tabular}

NMR spectroscopy

Raman spectroscopy

UV-VIS spectrophotometry

LC
- Amenable to process analytics, fiber optics [113, 130, 254]

- High-throughput [29, 215, 227, 248]

- Nondestructive [248, 254]

- Excellent, detailed structural analysis [80]

- Noninvasive [80]

- Nondestructive $[80,126]$

- Quantitation does not require pure calibration standards [126]

- Not hindered by presence of water [73]

- Relatively little to no sample preparation [73]

- Can measure solid, liquid, or gas [124, 128]

- Nondestructive [73]

- Field-portable [115, 118]

- Amenable to process analytics $[117,130]$

- Multiple excitation sources, so analysis can be tailored to analyte (UV, VIS, NIR) [121, 124]

- Surface enhancement using noble metals (SERS, SERRS) [128]

- Complimentary to FTIR [128]

- High-throughput [73, 148, 150]

- Lower cost, simple instrumentation [126]

- Convenience [126]

- Accuracy [126]

- Selectivity [126]

- Good sensitivity [126]

- Nondestructive [89]

- Applicable to wide range of molecular polarities [280]

- Can separate thermally unstable or non-volatile molecules [281]
- May require long analysis time [73]

- Spectra often have considerable peak overlap, especially in the lignin region $[80,102]$

- Less sensitive than other spectral techniques [80]

- Expensive [126]

- Weak signal [128]

- Stray light into the spectrometer must be prevented [121, 124]

- Fluorescence can dwarf Raman intensities [171]

- Limited qualitative analysis applications since low absorption maxima and minima [126]

- Time consuming analysis depending on matrix complexity, and desired separation $[27,111]$

- Sample clean-up required [173] 
Table 2 (continued)

\begin{tabular}{|c|c|c|}
\hline Technique & Advantages & Disadvantages \\
\hline & $\begin{array}{l}\text { - Selective interaction between mobile and stationary } \\
\text { phase [280] }\end{array}$ & \\
\hline & • Nondestructive [281] & \\
\hline & $\begin{array}{l}\text { - Analyst can tailor phases to maximize separation } \\
\text { (gradient elution) }[280,281]\end{array}$ & \\
\hline \multirow[t]{4}{*}{ GC } & $\begin{array}{l}\text { - Can selectively analyze only volatile components of } \\
\text { mixture such as ethanol fermentation liquor [173] }\end{array}$ & $\begin{array}{l}\text { - Requires volatile analytes whether } \\
\text { naturally or through derivatization [27] }\end{array}$ \\
\hline & $\begin{array}{l}\text { - Limited sample clean-up required, if using technique } \\
\text { like headspace GC [173] }\end{array}$ & $\begin{array}{l}\text { - Can require extensive sample preparation } \\
{[27,282]}\end{array}$ \\
\hline & - Sharper peaks/better resolution than LC [282] & $\begin{array}{l}\text { - Time consuming analysis depending on } \\
\text { matrix complexity, and desired separation } \\
{[173]}\end{array}$ \\
\hline & & • Destructive [282] \\
\hline \multirow[t]{4}{*}{ Pyrolysis GCMS/MBMS } & - Requires little sample/sample preparation [49] & - Destructive [44] \\
\hline & $\begin{array}{l}\text { - Easy sample preparation [49] } \\
\text { - Lignin does not need to be isolated [44] }\end{array}$ & - Complex data analysis [44] \\
\hline & $\begin{array}{l}\text { - Provides structural information of major pyrolysis } \\
\text { products [49] }\end{array}$ & \\
\hline & - Can be high-throughput [47] & \\
\hline \multirow[t]{2}{*}{ TGA } & $\begin{array}{l}\text { - Rapid compared to standard techniques for biomass } \\
\text { analysis [52-54] }\end{array}$ & - Destructive [52-54] \\
\hline & - Good for polymers such as cellulose and lignin [53] & $\begin{array}{l}\text { - Limitations since temperature variation } \\
\text { must cause change in analyte mass [53] }\end{array}$ \\
\hline \multirow[t]{4}{*}{ XRD } & - Popularity in literature [79] & - Low resolution/specificity $[79,91]$ \\
\hline & • Only technique capable of yielding qualitative/ & - Texture detrimental to analysis of CrI [79] \\
\hline & quantitative data of compounds in a mixture [126] & - Qualitative/semi-quantitative analysis [79] \\
\hline & & - Safety \\
\hline \multirow{3}{*}{$\begin{array}{l}\text { Wet chemistry (acidolysis, } \\
\text { thioacidolysis, nitrobenzene } \\
\text { oxidation, acid hydrolysis, etc.) }\end{array}$} & - Well established and accepted techniques [283] & • Laborious [73] \\
\hline & & - Toxicity $[20,28,283]$ \\
\hline & & - Do not account for all lignin [283] \\
\hline
\end{tabular}

reported in the literature $[62,63,79,88,91,140,142,144$, 155-157, 165, 166]. A technique was developed using FTRaman spectroscopy coupled with univariate and multivariate analysis [140, 142]. Univariate analysis consisted of comparing the ratio of the 380 and $1,096 \mathrm{~cm}^{-1}$ bands. A calibration was generated that provided good correlation $\left(R^{2}=0.992\right)$ and higher accuracy than the wide-angle X-ray scattering (WAXS) technique. The multivariate analysis coupled FT-Raman spectra with either the WAXS or univariate Raman crystallinity indices. The univariate-Raman-partial least squares (PLS) model proved superior when compared to the WAXS PLS model, showing the extension of FT-Raman spectroscopy to CrI estimation.

Schenzel et al. also developed a CrI calculation technique using FT-Raman spectroscopy [156, 157]. The ratio of intensities from vibrational modes at 1,481 and $1,462 \mathrm{~cm}^{-1}$ was compared, as these were identified as crystalline and amorphous cellulose, respectively. The measured CrIs showed reasonable linear correlation with results obtained using NMR spectroscopy. Schenzel and coauthors also rapidly quantified the transformation of cellulose I to cellulose II using FTRaman spectroscopy and PLS regression [155]. Cellulose structural transformation during AFEX treatment of corn stover was monitored using the ratio between the 350 and $380 \mathrm{~cm}^{-1}$ vibrational modes, again, showcasing the utility of FT-Raman spectroscopy for examining conversion of cellulose crystalline forms. The standard techniques for analyzing cellulose transformation include NMR and WAXS, and are laborious and costly [155].

The ratio of syringyl (S) to guaiacyl $(G)$ lignin in plant cell walls has been shown to be a valuable assessment of lignin degradability, as $\mathrm{S}$ lignin is more reactive [167, 168]. The quantitation of $\mathrm{S}, \mathrm{G}$, and $p$-hydroxyphenol $(\mathrm{H})$ lignin can allow the classification of plants into gymnosperm (G lignin), angiosperm (S-G lignin), and herbaceous (S-G-H lignin), with some exceptions, such as eucalypts, which are classified as angiosperms but are known to contain H lignin [94, 169, 170]. Sun et al. developed a rapid technique for determining $S / G$ ratios in a variety of feedstocks including Eucalyptus and Arabidopsis [161]. Spectral regions corresponding to $\mathrm{S}$ and 
$G$ lignins were determined from commercially prevalent model compounds and then used in deconvoluting the Raman spectra. The results were compared with those obtained from pyroGCMS, and a calibration equation was generated with good correlation $\left(R^{2}=0.983\right)$. Contributions from cellulose were problematic, however, in the spectral regions used for $\mathrm{S}$ and $\mathrm{G}$ lignin quantitation which could have led to the higher ratios calculated from the Raman spectra.

Ona et al. have also explored the use of FT-Raman for the quantitation of the S/G ratio in Eucalyptus using second derivative Raman spectra coupled with thioacidolysis results to construct a PLS regression model with a prediction coefficient of determination of 0.935 [148]. Other applications of FTRaman spectroscopy coupled with PLS for high-throughput prediction of useful metrics developed by Ona et al. include the determination of hemicellulosic neutral sugar composition [150] and the analysis of wood constituents (holocellulose, $\alpha$ cellulose, hemicellulose, lignin, extractives, etc.) $[149,152$, 153]. The coefficient of determination for the analysis of hemicellulosic sugars ranged from 0.347 for mannose to 0.800 and 0.939 for glucose and xylose, respectively, indicating good screening utility for the more abundant monosaccharides [150]. Remarkably, the models containing wood constituents all produced quantitative calibration correlation $(>0.99)$, but the prediction correlation ranged sporadically from 0.209 (extractive free hemicellulose) to 0.902 (holocellulose), indicating screening potential, but limited quantitative capability [149]. A similar study was later performed to assess Eucalyptus viability for kraft pulp production [153]. An extensive analysis of chemical and physical properties of these woods included mono- and polysaccharide, lignin, and extractive contents, lignin $\mathrm{S} / \mathrm{G}$ ratio, as well as basic density, ray/axial parenchyma, vessels, fiber, and cell wall, content and dimensions.

Another noteworthy study using FT-Raman spectroscopy measured 98 temperate hard- and softwoods, and Brazilian and Honduran tropical woods [147]. A pattern recognition genetic algorithm was developed to draw out key spectral characteristics for each wood type. The identification of these features enabled clustering by type using principal component analysis (PCA). The calibration model was validated using a separate set of ten wood spectra. The genetic algorithm identified eight essential spectral features, which allowed distinct classification clustering in PCA. FT-Raman spectroscopy allowed the identification of characteristic vibrational modes from substances such as carbohydrates, polyphenols (i.e., flavonoids), terpenoids, and alkaloids in a variety of plants [158]. The authors used a combination of spectroscopy and hierarchal cluster analysis to produce a reliable, high-throughput technique for chemotaxonomy characterization. Larson and Barsberg measured model lignin monomers and developed an extensive evaluation of vibrational mode assignments using both FT-Raman spectra and density functional theory (DFT). DFT allowed for an accurate prediction of a molecule's vibrational modes based upon what are termed first principles or basic electronic structure theory [146].

An application of FT-Raman for ethanol production process control was exemplified by the development of principal component regression (PCR) and PLS techniques using the simultaneous quantitation of glucose and ethanol with FTRaman spectroscopy, coupled with a parallel HPLC analysis for calibration. The authors report significant linear correlations using a variety of calibration techniques $\left(R^{2}=0.9\right.$ or greater) [160]. Online process monitoring of fermentation is becoming routinely utilized in many industrial settings. Lastly, FT-Raman spectroscopy was used to study carbonyl groups in synthesized and conifer lignin after reduction/oxidation [164].

\section{Near-Infrared Dispersive Raman Spectroscopy}

Recent advances in near-infrared, dispersive Raman spectroscopy have elucidated key attributes for biomass analysis. A homebuilt, near-infrared, dispersive, multichannel Raman spectrometer was shown to provide superior spectral resolution to FTRaman after $15 \mathrm{~s}$ acquisition time when measuring lignin and lignin model compounds with 1,064 nm excitation [171]. This instrumentation was also employed in the study of a variety of feedstocks with emphasis on herbaceous plants such as switchgrass and Miscanthus [73]. Raman spectra were coupled with S and $\mathrm{G}$ lignin content determined by thioacidolysis extraction, and detection with GCMS. A robust PCR model allowed for the rapid, accurate prediction of $\mathrm{S}$ and $\mathrm{G}$ lignin for most of the feedstocks $\left(R^{2}=0.985-0.986\right)$.

Near-infrared Raman spectroscopy using $785 \mathrm{~nm}$ excitation has been used to quantify glucose (detection limit $=3 \pm 2 \mathrm{mg}$ $\mathrm{mL}^{-1}$ ) and xylose (detection limit $=1 \pm 1 \mathrm{mg} \mathrm{mL}^{-1}$ ) simultaneously using a multi-peak fit, measure ethanol (detection limit $=6 \mathrm{mg} \mathrm{mL}^{-1}$ ) in complex reaction matrices, and gauge which biomass pretreatment/extraction methods lowered detection limits $[172,173]$. It was determined that soaking in aqueous ammonia (SAA), thereby removing lignin from plant cell walls, or extracting with water, ethanol, or hexane significantly reduced glucose detection limits (SAA detection limit $=5 \mathrm{mg} \mathrm{mL}^{-1}$; extraction $=5-6 \mathrm{mg} \mathrm{mL}^{-1}$ ).

Li et al. used $785 \mathrm{~nm}$ excitation to study lignin depolymerization during ionic liquid and dilute acid pretreatments of pine, Eucalyptus, switchgrass, and AFEX pretreatment of corn stover [174-176]. The results illustrated that ionic liquid pretreatment improved saccharification yields through lignin removal. The use of online $785 \mathrm{~nm}$ excitation Raman spectroscopy was used to investigate the production line from wood to cellulose fiber [177]. This analysis included lignin, cellulose, and resin distribution in the cell wall, additives found inside regenerated cellulose fibers, and online monitoring of magnesium sulfite hexahydrate trihydrate 
phase transition during the $\mathrm{SO}_{2}$ recovery cycle of the acidmagnesium bisulphite pulping reaction.

\section{Surface Enhanced Raman Spectroscopy}

The application of surface-enhanced Raman scattering (SERS) using silver particles to MWL isolated from black spruce was also studied [141]. SERS has previously been shown to enhance the signal of an adsorbed (or in close proximity) analyte due to the electric field generated from the metal. This allows the enhanced detection of weak Raman scatterers. Although some MWL peaks were clearly enhanced between 250 and $1,800 \mathrm{~cm}^{-1}$, other spectral features appeared to be lost or significantly broadened. This included the most intense lignin spectral region near $1,600 \mathrm{~cm}^{-1}$. The authors also investigated the use of SERS on Wiley-milled wood and concluded that SERS presents a viable technique for selectively measuring lignin in wood samples without first isolating the lignin. More research is needed in the application of SERS to lignocellulosic biomass, given the inherent problems in reproducibility and spectral analysis [128].

\section{Resonance Raman Spectroscopy}

In resonance Raman (RR) spectroscopy, there is an overlap between an electronic transition of an analyte and the excitation wavelength selected by the analyst $[124,128]$. This results in the promotion of the molecule to real rather than "virtual" electronic states, producing more intense Raman spectra, a higher degree of selectivity since solely molecules with electronic transitions near the excitation wavelength will be enhanced, and an elimination of interfering fluorescence. A novel application of RR spectroscopy using visible excitation was developed for the study of lignin radicals [178]. These radicals are known to be intermediate species in the formation/enzymatic degradation of lignin and provide insight into the mechanisms by which lignin is naturally synthesized or depolymerized. A lignin radical band was detected at $1,570 \mathrm{~cm}^{-1}$, regardless of the feedstock. Bands at 1,597 and $1,599 \mathrm{~cm}^{-1}$ were found to represent $\mathrm{G}$ and $\mathrm{S}$ lignin radicals, respectively. This work was a follow-up study to an earlier publication where the authors show the utility of RR spectroscopy for selectively enhancing lignin spectral intensities using 400 and $500 \mathrm{~nm}$ excitation, although the excitation profile at the latter wavelength is reduced such that not all lignin groups are enhanced [179]. Fluorescence was prevented by Kerr gating. The authors used RR difference spectra to probe the structural changes caused by enzyme-mediator systems such as laccase2,2'-azino-bis(3-ethylbenzthiazoline-6-sulfonic acid). Syringyl groups were found to contribute significantly to spectra collected using $400 \mathrm{~nm}$ excitation. A similar application was employed by Saariaho et al. [180] and Jaaskelainen et al. [181]. Lignin detection in chemical and thermomechanical pulps was resonantly enhanced using 400 and $470 \mathrm{~nm}$ excitation, elucidating weak spectral features and allowing the identification of new structures formed during the reactions.

Ultraviolet resonance Raman (UVRR) spectroscopy has also been used in the analysis of biomass, specifically lignin, due to an electronic absorption in this region [13]. Due to the higher energy of ultraviolet wavelengths, photodegradation of the sample must be prevented, often through the use of rotating stages and low laser powers. Saariaho and coauthors have been one of the leading teams developing UVRR for lignin and lignin model compounds analysis [182, 183]. Wavelength regions characteristic to $\mathrm{S}, \mathrm{G}$, and $\mathrm{H}$ lignin model compounds were determined through the use of 229, 244, and $257 \mathrm{~nm}$ excitation. H structures were most intense when excited with a 244-nm wavelength and revealed signature spectral features at $1,167-1,179$ and 1,214-1,217 $\mathrm{cm}^{-1}$. G compounds were most intense using $257 \mathrm{~nm}$ excitation, with features at 704-791, 1,155-1,158, 1,185-1,187, and 1,279-1,289 $\mathrm{cm}^{-1}$, while spectra of S model structures excited with 244 or $257 \mathrm{~nm}$ laser wavelengths revealed similar intensities at 962-981, 1,3301,333 , and 1,506-1,514 $\mathrm{cm}^{-1}$. Polysaccharide peaks, which would overlap many of these spectral regions using visible or NIR excitation, were minor, such that these spectral regions could be applied to whole wood samples. PLS was used to develop a model capable of finding key spectral signatures for a variety of lignin model compounds, including condensed, conjugated, and stilbene model compounds.

UVRR spectroscopy was used for analyzing tropical hardwoods, identifying extractable components in wood, and studying changes in pine chemical structure after heat treatment [78, 184-186]. A PCA analysis of UVRR tropical hardwood spectra allowed the determination of characteristic vibrational modes using loadings and scores plots [78], while measurement of hexane and acetone-water extracts revealed lipophilic and hydrophilic molecules, respectively, such as resin, fatty acids, oleophilic structures, and bands similar to those of pinosylvin $[185,186]$. UVRR spectra showed that lignin was somewhat soluble in acetone when heated to $180^{\circ} \mathrm{C}$, and that once soluble lignin was removed from pine, the unextractable lignin structure was unaltered [184].

Other uses of UVRR include the study of bleaching and photoyellowing of thermomechanical pulps [180, 187], the effects of bleaching on residual lignin [188], and the photodegradation of hard- and softwood lignin with a UV laser [189]. These studies showed the applicability of UVRR to identify degradation products while also monitoring temporal changes in the biomass. Additionally, Jääskeläinen et al. developed a novel, rapid technique for quantifying lignin and hexenuronic acids in bleached hardwood kraft pulps [190]. The authors relate that most lignin quantitation methods were developed on unbleached pulp, and therefore suffer in accuracy when bleached pulps are measured. Lignin contents were determined from the peak height of aromatic bands in UVRR spectra, even when the total lignin content 
was less than $1 \%$. Experimental lignin contents were found to linearly correlate with kappa number $\left(R^{2}=0.905\right)$ and lignin kappa number $\left(R^{2}=0.988\right)$.

\section{Raman Microscopy}

Raman microscopy has been used to image biomass in real time while being chemically pretreated, as well as compare the molecular and chemical structures of different feedstocks [191-196]. The distribution of cellulose and lignin in various corn stover fractions, using hyperspectral Raman imaging, showed distinct differences in cell wall composition depending on the portion of the plant [194]. Lignin and cellulose content were highest in sclerenchyma cells and tracheids and lowest in parenchyma cells. The mapping technique was extended to Eucalyptus globulus and accentuated differences in lignin structure. Confocal Raman microscopy allowed the effects of ionic liquid (IL) pretreatment of corn stover to be visualized [195]. The authors developed an appropriate spectral subtraction method to remove intense IL spectral bands and monitored temporal, cell wall, and compositional changes. Dissolved cellulose and lignin were removed, allowing residual solids to be imaged as the IL pretreatment progressed. Cell wall swelling occurred mainly in the secondary wall, whereas the IL did not cause significant swelling in the compound middle lamella. Sclerenchyma cells and tracheids showed increased disfigurement from the IL pretreatment, relative to parenchyma cells. Solubilization of lignin rapidly occurred in the secondary walls, without cellulose dissolution, while both lignin and cellulose were quickly removed from tracheids. Cellulose nanocrystals (CNCs) from wood pulp and microcrystalline cellulose, and CNC-polypropylene (PP) composites were studied using Raman mapping [196]. CNCs were shown to aggregate in PP, leading to poor overall spatial distribution. Materials made from renewable substances like CNC-composites are of growing interest, as they have potential to replace materials made from petroleum.

\section{Summary}

Applications concerning lignocellulosic biomass structure, degradation, product formation, etc., show the powerful capability of Raman spectroscopy to provide both detailed qualitative information and, in some cases, high-throughput, quantitative results. The crucial difference in these analyses stems from the researchers' choice of excitation wavelength. It is apparent that with further developments in Raman spectroscopy field portability, $[114,115,118]$ coupled with the power of chemometrics to extract and process useful data rapidly [107], Raman spectroscopy will continue to grow as a high-throughput analytical tool.

\section{Fourier Transform Infrared Spectroscopy $(\sim 2,500-25,000 \mathrm{~nm})$}

Fourier transform infrared spectroscopy (FTIR), another nondestructive analytical tool, is considered to complement Raman spectroscopy, since vibrational modes that are Raman active often are weak in infrared spectra, and vice versa. This is due to a difference in the selection rules. In Raman spectroscopy, a change in the polarizability (electron cloud distortion) is paramount to obtaining signal, while a dipole change is required for a vibrational mode to be infrared active. Another difference between the two techniques is that in IR spectroscopy, molecules are promoted to higher energy levels, while in Raman spectroscopy, a molecule is promoted to a short-lived "virtual" state and immediately relaxes. Due to the differences in the characteristic spectra of a molecule, conjunctive use of the two techniques can provide a better overall structural analysis $[119,120,128]$.

FTIR spectroscopy has often been used for analyzing biomass structure and monitoring changes that occur from physical and/or chemical treatments $[45,51,61,62,67,69$, $72,88,89,145,154,158,160,165,175,176,184,187$, 197-215]. The utility of FTIR for the analysis of wood have been previously reviewed $[131,216]$. Çentiköl and coauthors used FTIR spectroscopy to study structural changes following pretreatment of Eucalyptus with ionic liquid [62]. Peaks associated with $\mathrm{C}=\mathrm{O}$ stretches in ketones, esters, and carbonyls, as well as $\mathrm{C}-\mathrm{O}$ modes in syringyl lignin were found to decrease in intensity; however, the complex nature of plant cell walls prevented direct analysis of the chemical changes using solely FTIR spectroscopy. Attenuated total reflection-FTIR spectroscopy was also used to elucidate the chemical/physical changes of corn stover following AFEX pretreatment [175]. The ratio of peak areas from the 1,510 to $900 \mathrm{~cm}^{-1}$ bands was used to calculate the lignin/cellulose content. This ratio decreased from 0.58 , before pretreatment, to 0.11 after AFEX treatment. A comparison between FTIR spectra of untreated and dilute acid pretreated switchgrass showed the lignin/cellulose ratio (using the $1,510 / 900 \mathrm{~cm}^{-1}$ peak area ratio) to increase from 0.49 to 0.67 after acid treatment, while IL treatment lowered the ratio to 0.13 , indicating significant lignin removal [176].

PCA and FTIR spectral data were used to classify tropical hardwoods [78]. Loadings plots for different PCs were used to determine key spectral differences among the samples, which included $\mathrm{C}=\mathrm{O}, \mathrm{C}-\mathrm{O}$, and $\mathrm{C}-\mathrm{O}-\mathrm{C}$ moieties from $\mathrm{xy}-$ lan, $\mathrm{S}$ and $\mathrm{G}$ lignin, tannin, and $\mathrm{C}-\mathrm{O}$ stretches of alcohols, ethers, and carbonyl groups. Differences in lignin and carbohydrate structure could be visually identified from the spectra, such as $\mathrm{S} / \mathrm{G}$ lignin and acetyl groups in xylan. FTIR microspectroscopy was used to monitor the effects of photo-induced degradation on sugi sapwood [207]. The authors illustrate measuring the depth of degradation into the 
wood with irradiation time. FTIR and neural network algorithms allowed the classification of mutant maize cell wall components during development [209].

FTIR and PLS allowed the determination of key chemical parameters in two energy grasses that could be extended to the rapid screening of other feedstocks in determining biomass conversion-to-fuel suitability [199]. Prediction models for nitrogen content and alkali index showed coefficients of determination of 0.938 and 0.937 , respectively. The authors attempted to predict carbon and ash content with less success $\left(R^{2}=0.568,0.482\right)$, although further optimization is planned to improve model robustness.

Photoacoustic FTIR spectroscopy coupled with PLS was employed for hard- and softwood compositional analysis [217]. This technique was chosen due to lack of morphological sensitivity, the probing of larger sample quantities, and little to no sample preparation required, significantly increasing analysis throughput. Spectral data were combined with capillary zone electrophoresis carbohydrate quantitation, and with wet chemical determination of kappa number, to construct PLS predictive models. Prediction of xylose, glucose, mannose, arabinose, galactose, hexeuronic acid, as well as kappa numbers was shown to be reasonably accurate $\left(R^{2}=0.74-0.93\right)$. The model was extended to xylan, glucomannan, and cellulose prediction. Jones et al. used online thermal emission mid-IR spectroscopy to determine the composition of a moving stream of 96 hard- and softwood chip samples [206]. PLS was used to predict glucan, hemicellulose, lignin, and extractives from a calibration model consisting of the spectral data and reference values, with softwood hemicellulose and lignin showing the most accurate predictions. Transmission and diffuse reflectance FTIR coupled with PLS regression enabled predictions of extractive, lignin, and carbohydrate contents and basic density of pine [218]. The diffuse reflectance model was preferred due to facile sample preparation. Correlations ranged from 0.58 (carbohydrates) to 0.87 (extractives, basic density).

FTIR has also been used for quantitation of sugars in pretreated biomass liquors [211]. Glucose, xylose, mannose, galactose, 5-hydroxymethyl-2-furfural, and acetic acid were quantified in dilute acid pretreated, hard- and softwood slurries. PLS regression models composed of HPLC results and IR spectral data could rapidly predict compounds in reactor slurries online, eliminating tedious wet chemical chromatography analysis. The authors employed attenuated total reflectance to reduce spectral interference from water. In a similar study, Rodrigues et al. used FTIR/PLS for the quantification of monomeric sugars in E. globulus $\left(R^{2}=0.83-0.94\right)$ [219]. The authors also extended a previously developed univariate analysis method for E. globulus lignin to monosaccharides using 12 spectral peaks between 800 and $1,800 \mathrm{~cm}^{-1}$ for calibration $\left(R^{2}=0.81-0.93\right)$.

FTIR and Raman spectroscopies were used for the identification of substances extracted from plants [158], the determination of the degree of substitution after carboxymethylation of non-starch polysaccharides [213], changes in the chemical structure of softwood cellulose paper after hydrothermal degradation [154], and the monitoring of ethanol production for process and quality control [160]. In this latter study, glucose, ethanol, and optical density were simultaneously detected. Prediction errors were higher in Raman spectroscopy models (PLS, PCR) due to inefficient Raman scattering from the cultures. Nonetheless, this study illustrates the applicability of the marriage of IR and Raman spectral data for rapid process control.

The structure of lignin has been assessed using FTIR spectroscopy [61, 67, 69, 89, 90, 202, 204, 220]. FTIR allowed the identification and characterization of the regeneration of lignin from pine and Eucalyptus, following IL pretreatments [61]. Different ILs were studied, and the authors determined that lignin could only be regenerated from those using chloride anions, and that 1-butyl-3-methylimidazolium chloride provided a regenerated lignin with the highest aromatic content. The use of 1-ethyl-3-methylimidazolium chloride resulted in regenerated lignin with the highest thermal stability. Therefore, depending on the lignin application, an appropriate IL can be selected to maximize ideal properties. Lignin, isolated from sugar cane and curaua by acidolysis, was classified using FTIR to understand the mechanism involved in a newly developed technique for natural fiber production [67]. Bermello and coauthors characterized the acid insoluble lignin isolated from Eucalyptus pellita, Eucalyptus citriodora, and Eucalyptus saligna [202]. Other applications of FTIR to lignocellulosic biomass include studies of cellulose crystallinity after pretreatment [88], biooil composition following pyrolysis of a biopolymer/polypropylene blend [45], rapid plant root compositional analysis using diffuse reflectance mid-IR spectroscopy [212], and the identification of volatile substances following devolatilization of pine wood, wood pellets, olive stones, and hazelnut shells [203].

FTIR has begun to show promise as a high-throughput technique. Although many of the cited examples explore qualitative biomass characterization, a few studies have shown the utility of FTIR for rapid quantitation and process control. FTIR coupled with chemometrics enables reduction in analysis time and cost, robust prediction models, and with fiber optics, remote and online sensing.

\section{Near-Infrared Spectroscopy $(\sim 700-2,500 \mathrm{~nm})$}

NIR has become pervasive in the literature during the last decade or so $[24,29,41,53,63,116,200,215,221-254]$ due to the simplicity of the instrumentation and sample handling as often samples are measured with virtually no preparation, and its nondestructive, high-throughput, and process analytical capabilities $[29,113,122,129,215,217,248,254]$. Unlike 
Raman or mid-infrared spectra that characterize fundamental vibrational modes, the combination and overtone bands associated with $\mathrm{C}-\mathrm{H}, \mathrm{N}-\mathrm{H}, \mathrm{O}-\mathrm{H}$, and $\mathrm{S}-\mathrm{H}$ moieties measured in NIR spectra are subtle and require deconvolution typically through the use of chemometrics, to aid in extracting useful parameters [108, 109]. This lack of distinct features arises from the fact that spectral overtone and combination bands are much weaker in intensity than fundamental vibrational modes. NIR applications for environmental, food, and wood and paper analysis have previously been reviewed [116, 248, 254].

One of the main applications of NIR has been the development of biomass composition prediction models. Standard techniques, such as the two-step acid hydrolysis [20], are coupled with NIR spectral data, producing robust calibration matrices capable of predicting future sample metrics, eliminating the need to perform laborious wet chemical techniques on all samples. These models rapidly screen large sample sets of different feedstocks. NIR coupled with PCA and PLS regression enabled the identification of outliers in rice and Arabidopsis cell wall mutants [245]. Mahalanobis distances were calculated (a measurement of how close a sample lies to the calibration mean) to determine sample set outliers. Monosaccharide analysis was performed using trifluoroacetic acid hydrolysis and high-performance anion exchange chromatography. These standard data were conjoined with NIR spectral data for PLS regression generating a 206 sample calibration set. Correlation between the experimental and predicted monosaccharide content was 0.98 . NIR and canonical variance analysis was employed to classify the heart- and sapwood of eight eucalypt species [63]. The authors show the screening utility of NIR without biochemical data. After comparing to compositional data, outliers were postulated to represent samples with high carbohydrates and low lignin.

A similar analysis was performed for the compositional analysis of 508 commercial hybrid corn stover samples to gauge variability between samples grown throughout the Midwest USA [247]. Standard wet chemical techniques were performed on 77 feedstocks, and PLS regression was employed to predict the composition of the remainder, using 13 chemical components. Analysis of variance revealed the three largest sources of variation between the samples were due to harvest year, location, and genetic variety. Variations of these techniques are increasingly prevalent throughout the literature, depicting the competency of NIR to screen a multitude of samples rapidly and accurately for key characteristics and environmental conditions in the development of second generation biofuel feedstocks. In addition to rice [245], Arabidopsis [245], and corn stover [29, 53, 242, 247, 249, 251], applicability of NIR for compositional analysis has also been investigated using switchgrass [29, 233, 234, 244], Eucalyptus [63, 200, 222, 224, 229, 240, 241,
243, 246], rice straw [231], wheat straw [29], flax [41], hemp [41], kenaf [41], palm [41], sugarcane [41], cotton [41], conservation grasslands [221], loblolly pine [232, 253], and aspen [250, 253] to name a few.

Other NIR screening techniques have rapidly provided information that would have previously been quite laborious to achieve. One arena NIR has had a major impact upon is the understanding of natural and engineered genetic variation among feedstocks. Stackpole and coauthors studied natural genetic variance in chemical composition between 467 E. globulus trees [246]. NIR was also applied to cellulose content prediction in Eucalyptus nitens [243]. The authors found their technique to accurately select improved genotypes with respect to cellulose content, enabling a rapid analysis of tree breeding.

Radial variation in kraft pulp yield (KPY) and cellulose content of three E. globulus plants, grown at sites exhibiting different annual rainfall, were studied using NIR [226]. Linear correlation with standard techniques showed good agreement ( $R^{2}=0.86$ for KPY, 0.91 for cellulose content). The authors determined that wood samples from the cambium had up to $8 \%$ higher potential KPYs than in the pith. Sites with more rainfall provided higher KPY and cellulose contents.

Temporal and spatial variation among switchgrass populations was studied by Schmer and coauthors [244]. Effects of chemical composition and variation on theoretical ethanol yields were predicted and calculated. Ten fields were compared, with varying average rainfall and temperature, and harvest year differences. The authors determined that drought conditions increased hemicellulose content. Field-to-field variation significantly affected expected ethanol yields. The authors also concluded that standardizing management practices such as harvest time and method, and fertilization rates could reduce the plant-to-plant variance seen in this study, and suggested that biorefineries test switchgrass before bioethanol production. The effect of crop maturity on corn stover compositional variance was also investigated to determine optimal harvesting and processing methodology to maximize fuel yields [242]. The study revealed decreases in soluble solids and increases in lignin and xylan with increasing maturation. While stalks and husks showed a similar composition, there was greater compositional variance in leaves, temporally. The authors attributed this to the leaf's greater metabolic activity due to photosynthesis. Interestingly, these results did not alter the energy content of the corn stover. The authors concluded that prolonged field collection of stover did not result in diminished value of the plant for combustion but would affect fermentation reactions, since ethanol yields are directly proportional to initial carbohydrate content.

Physical properties, such as air-dry density, microfibril angle, and stiffness of loblolly pine [232], and the surface longitudinal growth strain and shrinkage of a Eucalyptus 
hybrid (Eucalyptus urophylla $\times$ Eucalyptus grandis) [224] also utilized the predictive capabilities of NIR and chemometrics. Other developments include the successful classification of specific botanical fractions of corn stover using PCA [251] and the effect of drying temperature on wheat straw and corn stover chemical composition [230]. In this latter study, carbohydrate contents were compared when the feedstocks were dried at temperatures between 45 and $100{ }^{\circ} \mathrm{C}$. PCA revealed distinct classification capability based upon water content; however, quantitative analysis of sugar profiles conveyed no significant differences when using drying temperatures up to $100{ }^{\circ} \mathrm{C}$.

NIR applications extend to process control, including the monitoring of batch pretreatments, enzymatic hydrolysis, and ethanol production [113, 225, 227]. For example, Hames et al. discussed NIR use in dilute acid pretreatments [227]. Researchers could determine when hemicellulose had been efficiently removed from plant cell walls and the biomass was suitably prepared for cellulose enzymatic hydrolysis. NIR applications extended to fermentation monitoring as glucose uptake, biomass formation, ethanol and glycerin production, and acidification were measured using NIR spectroscopy and standard methods [225]. A PLS model predicted these parameters in fermentation liquors, revealing high correlation $\left(R^{2}=0.976-0.998\right)$.

Novel techniques for lignin analysis have been developed using NIR [24, 222, 240, 241, 250, 252]. Klason analysis of loblolly pine lignin was compared to lignin content determined from a PLS regression model [252]. Synthetic wood mixtures, containing blends of MWL and holocellulose, were also studied. Strong linear correlation between standard techniques and PLS predictions were measured. Lignin $S / G$ ratios were successfully predicted using a combination of pyrolysis GC-flame ionization detector coupled with NIR spectra and PLS. Optimal spectral preprocessing methods were developed, resulting in a $R^{2}$ of 0.97 [222].

These applications demonstrate the appeal of NIR coupled with chemometrics as an invaluable tool for screening biomass for optimal traits that will translate to higher fuel yields, for monitoring processes in real time, such that analysts can quickly identify complications during reactions rather than upon completion, and for determining useful structural parameters such as lignin $\mathrm{S} / \mathrm{G}$ ratios. Hames et al. further illustrate the power of NIR by comparing the cost/sample for their NIR technique, \$10/sample, to the cost using standard analytical methods, \$800-2,000 [227]. The high-throughput attributes of NIR permit the efficient, rapid screening of multitudes of potential feedstocks. The straightforward, economic instrumentation and simplicity of sample handling should herald further NIR research, allowing researchers to catalogue higher numbers of plants than with solely standard/wet chemical techniques.

\section{Fluorescence Spectroscopy}

The viability of fluorescence spectroscopy has been explored for studying biomass non-destructively $[125,165,204,214$, $236,237,255-258]$, as there is relatively little sample preparation required and the instrumentation is inexpensive, capable of on- or offline methodology, and can be fieldportable. Fluorescence spectroscopy measures the emission of electromagnetic radiation after a molecule has been excited to higher energy levels. Although this technique is more sensitive than some analytical instruments, fluorescence spectroscopy requires the presence of a fluorophore, whether intrinsic to the molecule, or through analyte labeling with a highly fluorescing species. Albinsson et al. studied the origins of lignin fluorescence [255]. Phenylcoumarone was identified as a likely acceptor during an energy transfer, resulting in fluorescence. A similar study probing the source of lignin fluorescence found biphenyls, coniferyl alcohol, and stilbenes to be prospective sources contributing to a broad fluorescence lignin peak [258].

Cellulose is not an intrinsically fluorescent substance. Studies of the causes of cellulose fluorescence have shown that solid state cellulose lends to higher fluorescence, and that compounds present in minute quantities, such as dityrosine, an amino acid involved in lignification, and cinnamic acids, might be fluorophore sources [256]. Fluorescence spectroscopy of bleached pine kraft pulps revealed an initial increase in fluorescence as peroxide bleaching progressed, due to removal of carbonyl moieties at 270 or $350 \mathrm{~nm}$ excitation, followed by a decrease in pulp fluorescence at $430 \mathrm{~nm}$ excitation due to carbonyl group formation after $\mathrm{O}_{2}$ and $\mathrm{O}_{3}$ delignification [257]. Fluorescence spectroscopy coupled with multivariate analysis (PCA and PLS) was used as a process analytical tool in the study of poplar and Northern red oak [236, 237]. Calibration and prediction models were developed for chemical and physical properties such as ash and extractive content, total lignin, and estimation of total holocellulose. The fluorescence models were compared to those generated from NIR analysis of identical samples. While the NIR models provided more accurate sample parameter predictions, fluorescence spectroscopy was suitable for the rapid screening and approximate calibration of biomass properties $\left(R^{2}=0.59-0.86\right)$ with the exception of holocellulose $\left(R^{2}=0.1-0.37\right)$.

Fluorescence spectroscopy has been used to study lignin contents of raw and ammonium fiber explosion pretreated rice straw [165]. Spectral data were coupled with sugar yields determined by HPLC to produce a PCR model. The fluorescence analysis did not exhibit good correlation with sugar yield, and the authors concluded that this could be due to residual lignin fragments in the plant cell wall and molecules such as cutin, suberin, sporopollenin, and cellulose continuing to fluoresce. Lignin, isolated from spruce and poplar, and a synthesized lignin model dehydrogenative 
polymer (DHP) were also studied using fluorescence spectroscopy [204]. Identical emission peak maxima indicated a structural similarity between the two trees and the DHP, confirming the applicability of using this DHP as a model compound. Intensity differences between the peak maxima resulted from differences in fluorophore structural arrangement within the polymers. Shifts in peak position between the DHP and woods were due to analyte microenvironment differences. Laser confocal fluorescence microscopy allowed the imaging of cellulose and lignin content in untreated and IL-pretreated switchgrass [214]. Cell wall swelling and dissolution of the biomass were visualized without the use of standard staining or embedding imaging techniques.

Lastly, a high-throughput analysis of fermentations in microtiter plates using fluorescence spectroscopy was developed by Samorski [259] and advanced by Kensy et al. [260]. This latter work describes the use of a measurement device entitled "BioLector" to screen a variety of media conditions by monitoring NADH spectral intensity increases, as well as strain screening, promoter characterization, an evaluation of operating conditions, and the development of a soluble fluorescent $\mathrm{pH}$ indicator for online determinations of fermentation $\mathrm{pH}$. The results of a later study confirmed agreement between bench- and laboratory-scale reactions [261]. To achieve higher throughput, the BioLector was integrated with a liquids handling robot [262].

\section{Ultraviolet-Visible Spectrophotometry}

Ultraviolet-visible spectrophotometry (UV-VIS) enables the nondestructive determination of a molecule's electronic transition to higher energy levels through the absorbance of light [125]. Quantitative analysis can be achieved using Beer's law, which shows a linear dependency of concentration and absorbance for dilute samples. Although UV-VIS spectrophotometry is typically used in conjunction with wet chemical techniques, a few recent developments are worth noting. Masuko and coauthors developed a high-throughput microplate technique for carbohydrate analysis using the phenol-sulfuric acid colorimetric method [263]. The scaled-down technique maintained high sensitivity and was less time consuming than standard methods. Extracted and isolated lignin from corn, alfalfa, bromegrass, and loblolly pine was used as a standard in the acetyl bromide spectrophotometric technique [11]. Lignin contents were found to be similar to those obtained from Klason lignin analysis. A simplified spectrophotometric technique for lignin quantitation of biomass dissolved in ionic liquids included measuring a solution of dissolved biomass at $440 \mathrm{~nm}$, using an extinction coefficient found from analyzing an ultrapure, organosolv-isolated lignin and using Beer's law [208]. The authors used FTIR to aid in selecting an appropriate standard to quantify lignin in unknown samples. Finally, UV spectra were used to gauge wheat straw lignin after an alkaline peroxide treatment [89].

\section{Nuclear Magnetic Resonance Spectroscopy}

Although NMR spectroscopy is not known as a highthroughput technique, its prevalence in biomass analysis makes it worth including in this review [34, 55-104]. In NMR spectroscopy, nuclei absorb radiation in the radio frequency range of the electromagnetic spectrum [126, 127]. Analytes are inserted into intense magnetic fields to create the splitting of electronic states necessary for absorption. NMR is described as a nondestructive, noninvasive technique, since the low radiofrequency excitation energy cannot bring about molecular physical/chemical changes, and therefore provides an excellent tool for determining unaltered molecular structures [80]. Quantitation can be achieved since non-overlapped peak areas represent the number of nuclei responsible for the peak, eliminating the need for calibration from pure compounds. However, the instrument cost and time required per sample, and peak overlap have limited quantitative applications. NMR techniques applied to lignocellulosic biomass have previously been reviewed $[55,76,80]$.

Perhaps the most widespread usage of NMR is for lignin molecular structure elucidation [59-61, 63-65, 67-71, 74, $75,81-87,89,90,93-98,102,104]$. Yan et al. quantified the $\mathrm{S} / \mathrm{G} / \mathrm{H}$ ratio of four varieties of isolated, ball-milled, switchgrass lignin from the spectral region between 102.5 and 162 ppm using ${ }^{13} \mathrm{C}$ NMR [92]. The effect of isolation technique on pine kraft lignin structure was investigated using 2D NMR [56]. 2D NMR correlates the chemical shift of one kind of nucleus with a like (homonuclear) or differing (heteronuclear) nucleus, resulting the ability to resolve overlapping peaks [80]. This technique has led to a variety of applications where 1D NMR resulted in insufficient spectral resolution. After detailed structural analysis, the authors determined that residual lignin was less structurally altered relative to dissolved lignin. Vinyl ether structures were present in dissolved, but not residual lignin, while stilbenes were also noticeably lower in residual lignin. The authors concluded that chemical changes within lignin fibers are limited, and that changes in residual lignin structure during pulping were due to a reduction in reactive moieties and concomitant increase in low-reactive structures. A similar technique elucidated the structure of and quantified the $\mathrm{S} / \mathrm{G} / \mathrm{H}$ ratio of $E$. grandis MWL [60]. The structure of this lignin was compared to other hardwoods. A previous study by these authors illustrated the use of multiple NMR techniques to quantify lignin structures in spruce MWL [59]. Whole lignin fractions 
were, for the first time, analyzed using non-degradative cell wall dissolution and 2D NMR [100, 101]. These non-degradative, solubilization techniques can be applied to polysaccharides and provide a clear picture of unaltered plant cell walls. 2D NMR difference spectra were employed to provide well-resolved spectral assignment of commonly overlapped peaks of unlabeled and ${ }^{13} \mathrm{C}$-labeled Gingko biloba DHPs [102]. Santos et al. probed structural variation among ten hardwood MWLs [87]. A new technique for $S / G$ quantitation was developed by calibrating the ratio of syringaldehyde/vanillin using nitrobenzene oxidation to that determined with ${ }^{13} \mathrm{C}$ NMR. Structural changes in E. globulus wood chips, after steam explosion, and treatment with a laccase-mediator system were determined using $2 \mathrm{D}$ and ${ }^{13} \mathrm{C}$ NMR [93]. Increases in $\mathrm{COOH}$ and phenolic $\mathrm{OH}$, and decreased $\beta-\mathrm{O}-4$ moieties, were found after steam explosion. The degree of condensation and secondary $\mathrm{OH}$ groups were detected following incubation with laccase. Various NMR methods were employed to evaluate switchgrass MWL before and after dilute acid pretreatment [86]. The authors confirmed spectroscopically that this was S-G-H lignin and found that the $\mathrm{S} / \mathrm{G}$ ratio decreased from 0.80 to 0.53 following acid pretreatment. The factors causing the overestimation of lignin content for mass balance closure, following the dilute acid pretreatment of corn stover, were examined [71]. The authors hypothesized that sugars and extractables may be the interferents causing lignin overquantitation. Pinto et al. showed that a variety of eucalypts, although considered angiosperms (S/G lignin), contained small amounts of $H$ lignin $[94,96]$. The linkages between polysaccharides and lignin were studied using model compounds ethyl ferulate (FA) and coniferyl alcohol (CA) [104]. Cross-coupled products were isolated and characterized using 2D NMR. The results revealed that these compounds readily coupled via free radical mechanisms, forming a variety of linkages and products. The authors also establish, for the first time, the transesterification of $8-\beta$-coupled FA/CA hydroxyl esters into lactones. Lignins isolated from fruit and vegetable fiber [58], corn stover [65, 71, 75], wheat straw [64, $89,90]$, sugarcane and curaua [67], loblolly pine [69], birch [68, 78], spruce [59, 70], Eucalyptus [61, 83, 84, 94], and Arabidopsis [74], to name a few, have also been structurally characterized.

NMR has also been used in the structural analysis of cellulose [34, 55, 66, 69, 72, 77, 79, 88]. Atalla and VanderHart reviewed the use of solid state ${ }^{13} \mathrm{C}$ NMR for native cellulose [55]. Solid state ${ }^{13} \mathrm{C}$ NMR has been commonly used for determination of cellulose crystallinity. Park et al. deconvoluted the $\mathrm{C} 4$ carbon peak as measured by ${ }^{13} \mathrm{C}$ NMR cross-polarization magic angle spinning (CP-MAS), since the peaks at 89 and $84 \mathrm{ppm}$ correspond to ordered and disordered structures, respectively. The CrI was calculated by dividing the area of the $89 \mathrm{ppm}$ peak by the total $\mathrm{C} 4$ peak area [79]. The CrI of switchgrass was measured, before and after cellulose-solvent-based pretreatment, using ${ }^{13} \mathrm{C}$ NMR
CP-MAS [88]. The authors also used NMR to conclude that fast hydrolysis rates and high glucan digestibility were attributable to greater substrate accessibility to cellulase following cellulose dissolution. Four species of Agave were investigated using ${ }^{13} \mathrm{C}$ NMR CP-MAS in order to characterize cellulose [72]. Cellulose crystallinity was determined using a two-peak integration of the $\mathrm{C} 4$ region, while a seven-peak nonlinear line-fit analysis of the $\mathrm{C} 4$ region was used to determine relative amounts of cellulose allomorphs and fibril surface. The authors concluded that agave crystallinity was similar to that of switchgrass, and that paracrystalline cellulose comprised over $50 \%$ of the total crystalline cellulose.

Lastly, NMR has been employed for the structural elucidation of whole biomass [34, 57, 62, 63, 73, 76, 78, 92, 99-101]. Applications include the ${ }^{13} \mathrm{C}$ NMR CP-MAS measurement of various tropical hardwoods and comparison of relative carbon abundance [78], and the correlation of NIR Raman spectral interpretation of a hardwood, softwood, and herbaceous feedstock to facilitate vibrational mode assignment and deduce likely sources of anomalous peaks [73]. 2D NMR enabled the structural characterization of eucalypts and calculation of the relative abundance of inter-lignin linkages and $\mathrm{S} / \mathrm{G}$ ratios $[62,63]$. Hedenström and coauthors developed a novel multivariate analysis technique using 2D NMR and soft independent modeling of class analogy. The model allowed lignin and polysaccharide cell wall alterations in poplar wood to be elucidated, without requiring the selection of representative peaks from complex spectra. Characteristic differences in lignin, hemicellulose, and cellulose were readily measured, validating the applicability of the technique. The model was extended to transgenic poplar, where the degree of pectin methylesterification had been modified. These changes, previously arduous to detect spectrally, were accurately predicted by the authors' model. Bardet et al. used ${ }^{13} \mathrm{C}$ solid state NMR for the analysis of decayed or waterlogged archaeological woods [57]. The authors achieved quantitation of the water, lignin, and cellulose content of wood from medieval canoes. Mansfield et al. reported a novel technique for studying whole plant cell walls using non-degradative preparation and solubilization, and 2D NMR [101]. The authors' technique is compared to a variety of common, deconstruction methods used for biomass compositional analysis such as thioacidolysis, nitrobenzene oxidation, and derivatization followed by reductive cleavage that tally only a small fraction of the total lignin.

\section{Conclusions}

The review provides an overview of how analytical spectroscopy has been utilized to qualitatively assess biomass for quintessential biofuel traits such as cellulose or lignin content, and quantitatively measure values such as glucose or 
ethanol production. Many ubiquitous standard methods suffer from tedious sample preparation, long and expensive analysis, and in general, the inability to screen sizeable plant sample sets. High-throughput techniques that can reliably predict biomass characteristics are mandatory to ensure that second generation feedstocks possessing significant attributes for biofuel production are isolated. Vibrational spectroscopy has become an accomplished analytical tool for rapid, biomass screening. However, these techniques systematically rely upon calibrating spectral data with standard methods to produce chemometric models. Comfortable dependence on these prediction models requires robustness levels such that samples inserted directly or well after the model's construction yield statistically similar results. Many spectroscopic applications illustrated here show promise for attaining high-throughput analysis of biomass, exhibiting large reductions in time and costs associated with the techniques. As this field progresses and researchers carefully produce validated calibration models capable of high accuracy, regardless of slight sample and instrumental variation, superior screening of dedicated bioenergy crops for traits enabling maximum fuel production can reduce global dependence on nonrenewable fuels.

Acknowledgments This review was supported as part of a collaboration between the Queensland Alliance for Agriculture and Food Innovation and the Joint BioEnergy Institute. The work conducted by the Joint BioEnergy Institute was supported by the Office of Science, Office of Biological and Environmental Research, of the US Department of Energy under contract no. DE-AC02-05CH11231.

Open Access This article is distributed under the terms of the Creative Commons Attribution License which permits any use, distribution, and reproduction in any medium, provided the original author(s) and the source are credited.

\section{References}

1. Perlack RD, Wright LL, Turhollow AF, Graham RL, Stokes BJ, Erbach DC (2005) Biomass as a feedstock for a bioenergy and bioproducts industry: the technical feasibility of a billion-ton annual supply. DOE/GO-102005-2135. Oak Ridge National Laboratory, Oak Ridge

2. Perlack RD, Stokes BJ (2011) U.S. billion-ton update: biomass supply for a bioenergy and bioproducts industry ORNL/TM-2011/ 224. Oak Ridge National Laboratory, Oak Ridge

3. Carroll A, Somerville C (2009) Cellulosic biofuels. Annu Rev Plant Biol 60:165-182. doi:10.1146/annurev.arplant.043008.092125

4. Karp A, Shield I (2008) Bioenergy from plants and the sustainable yield challenge. New Phytol 179(1):15-32

5. McKendry P (2002) Energy production from biomass (part 1): overview of biomass. Bioresour Technol 83(1):37-46. doi:10. 1016/s0960-8524(01)00118-3

6. Shepherd M, Bartle J, Lee DJ, Brawner J, Bush D, Turnbull P, MacDonel P, Brown TR, Simmons B, Henry R (2011) Eucalypts as a biofuel feedstock. Biofuels 2(6):639-657. doi:10.4155/bfs.11.136

7. Simmons BA (2011) Bioenergy from plants and plant residues. In: Altman A, Hasegawa PM (eds) Plant biotechnology and agriculture: prospects for the 21st century. Academic, Oxford, pp 495-506
8. Sims REH, Mabee W, Saddler JN, Taylor M (2010) An overview of second generation biofuel technologies. Bioresour Technol 101(6):1570-1580. doi:10.1016/j.biortech.2009.11.046

9. National Academy of Science (2009) Liquid transportation fuels from coal and biomass: technological status, costs, and environmental impacts. National Academies. http://sites.nationalacademies.org/ xpedio/groups/energysite/documents/webpage/energy_054519.pdf. Accessed 04/08/2013

10. Sticklen M (2006) Plant genetic engineering to improve biomass characteristics for biofuels. Curr Opin Biotechnol 17(3):315-319. doi:10.1016/j.copbio.2006.05.003

11. Fukushima RS, Hatfield RD (2001) Extraction and isolation of lignin for utilization as a standard to determine lignin concentration using the acetyl bromide spectrophotometric method. J Agric Food Chem 49(7):3133-3139. doi:10.1021/jf010449r

12. Hatfield RD, Grabber J, Ralph J, Brei K (1999) Using the acetyl bromide assay to determine lignin concentrations in herbaceous plants: some cautionary notes. J Agric Food Chem 47(2):628632. doi:10.1021/jf 9808776

13. Johnson DB, Moore WE, Zank LC (1961) The spectrophotometric determination of lignin in small wood samples. Tappi 44:793-798

14. DeMartini JD, Studer MH, Wyman CE (2010) Small-scale and automatable high-throughput compositional analysis of biomass. Biotechnol Bioeng 108(2):306-312. doi:10.1002/bit.22937

15. Dubois M, Gilles KA, Hamilton JK, Rebers PA, Smith F (1956) Colorimetric method for determination of sugars and related substances. Anal Chem 28:350-356. doi:10.1021/ac60111a017

16. Foyle T, Jennings L, Mulcahy P (2007) Compositional analysis of lignocellulosic materials: evaluation of methods used for sugar analysis of waste paper and straw. Bioresour Technol 98(16):3026-3036. doi:10.1016/j.biortech.2006.10.013

17. Godin B, Agneessens R, Gerin PA, Delcarte J (2011) Composition of structural carbohydrates in biomass: precision of a liquid chromatography method using a neutral detergent extraction and a charged aerosol detector. Talanta 85(4):2014-2026. doi:10.1016/ j.talanta.2011.07.044

18. International A (2007) Standard test method for acid-insoluble lignin in wood. ASTM International, West Conshohocken

19. Rabemanolontsoa H, Ayada S, Saka S (2011) Quantitative method applicable for various biomass species to determine their chemical composition. Biomass Bioenergy 35(11):4630-4635. doi:10. 1016/j.biombioe.2011.09.014

20. Sluiter JB, Ruiz RO, Scarlata CJ, Sluiter AD, Templeton DW (2010) Compositional analysis of lignocellulosic feedstocks. 1. Review and description of methods. J Agric Food Chem 58(16):9043-9053

21. Fengel D, Wegener G (1979) Hydrolysis of polysaccharides with trifluoroacetic acid and its application to rapid wood and pulp analysis. Adv Chem Ser 181:145-158 (Hydrolysis Cellul.: Mech. Enzym. Acid Catal)

22. Foster CE, Martin TM, Pauly M (2010) Comprehensive compositional analysis of plant cell walls (lignocellulosic biomass) part II: carbohydrates. J Visualized Exp (37). doi:10.3791/1837

23. Lapierre C, Monties B, Rolando C (1985) Thioacidolysis of lignin: comparison with acidolysis. J Wood Chem Technol 5(2):277-292. doi:10.1080/02773818508085193

24. Robinson AR, Mansfield SD (2009) Rapid analysis of poplar lignin monomer composition by a streamlined thioacidolysis procedure and near-infrared reflectance-based prediction modeling. Plant J 58(4):706-714. doi:10.1111/j.1365-313X.2009.03808.x

25. Chen CL (1992) Nitrobenzene and cupric oxide oxidations [of lignin in solution]. In: Lin SY, Dence CW (eds) Methods in lignin chemistry. Springer, Berlin, pp 301-321

26. Chundawat SPS, Balan V, Dale BE (2008) High-throughput microplate technique for enzymatic hydrolysis of lignocellulosic biomass. Biotechnol Bioeng 99(6):1281-1294. doi:10.1002/bit. 21805 
27. Decker SR, Brunecky R, Tucker MP, Himmel ME, Selig MJ (2009) High-throughput screening techniques for biomass conversion. Bioenergy Res 2(4):179-192. doi:10.1007/s12155-009-9051-0

28. International A (2007) Standard test method for determination of carbohydrates in biomass by high performance liquid chromatography. ASTM International, West Conshohocken

29. Liu L, Ye XP, Womac AR, Sokhansanj S (2010) Variability of biomass chemical composition and rapid analysis using FT-NIR techniques. Carbohydr Polym 81(4):820-829. doi:10.1016/j.carbpol.2010.03.058

30. Studer MH, De Martini JD, Brethauer S, McKenzie HL, Wyman CE (2009) Engineering of a high-throughput screening system to identify cellulosic biomass, pretreatments, and enzyme formulations that enhance sugar release. Biotechnol Bioeng 105(2):231238. doi:10.1002/bit.22527

31. Sun R-C, Sun X-F, Zhang S-H (2001) Quantitative determination of hydroxycinnamic acids in wheat, rice, rye, and barley straws, maize stems, oil palm frond fiber, and fast-growing poplar wood. J Agric Food Chem 49(11):5122-5129. doi:10.1021/jf010500r

32. Ruiz RO, Ehrman T (1996) HPLC analysis of liquid fractions of process samples for monomeric sugars and cellobiose. NREL, Golden

33. Blakeney AB, Harris PJ, Henry RJ, Stone BA (1983) A simple and rapid preparation of alditol acetates for monosaccharide analysis. Carbohydr Res 113(2):291-299. doi:10.1016/0008-6215(83) 88244-5

34. Hallac BB, Sannigrahi P, Pu Y, Ray M, Murphy RJ, Ragauskas AJ (2009) Biomass characterization of Buddleja davidii: a potential feedstock for biofuel production. J Agric Food Chem 57(4):12751281. doi:10.1021/jf8030277

35. Harris PJ, Henry RJ, Blakeney AB, Stone BA (1984) An improved procedure for the methylation analysis of oligosaccharides and polysaccharides. Carbohydr Res 127(1):59-73. doi:10.1016/ 0008-6215(84)85106-x

36. Lozovaya VV, Gorshkova TA, Yablokova EV, Rumyantseva NI, Valieva A, Ulanov A, Widholm JM (1998) Cold alkali can extract phenolic acids that are ether linked to cell wall components in dicotyledonous plants (buckwheat, soybean and flax). Phytochemistry 50(3):395-400. doi:10.1016/s0031-9422(98)00575-5

37. Lu F, Ralph J (1997) Derivatization followed by reductive cleavage (DFRC method), a new method for lignin analysis: protocol for analysis of DFRC monomers. J Agric Food Chem 45(7):2590 2592. doi:10.1021/jf970258h

38. Lu Y, Wei X-Y, Cao J-P, Li P, Liu F-J, Zhao Y-P, Fan X, Zhao W, Rong L-C, Wei Y-B, Wang S-Z, Zhou J, Zong Z-M (2012) Characterization of a bio-oil from pyrolysis of rice husk by detailed compositional analysis and structural investigation of lignin. Bioresour Technol 116:114-119. doi:10.1016/j.biortech.2012.04.006

39. Templeton David W (1994) Determination of ethanol concentration in biomass to ethanol fermentation supernatants by gas chromatography. NREL, Golden

40. Alves A, Gierlinger N, Schwanninger M, Rodrigues J (2009) Analytical pyrolysis as a direct method to determine the lignin content in wood. J Anal Appl Pyrolysis 85(1+2):30-37. doi:10.1016/j.jaap. 2008.09.006

41. Kelley SS, Rowell RM, Davis M, Jurich CK, Ibach R (2004) Rapid analysis of the chemical composition of agricultural fibers using near infrared spectroscopy and pyrolysis molecular beam mass spectrometry. Biomass Bioenergy 27(1):77-88. doi:10. 1016/j.biombioe.2003.11.005

42. Kuroda K, Nakagawa-izumi A, Mazumder BB, Ohtani Y, Sameshima K (2005) Evaluation of chemical composition of the core and bast lignins of variety Chinpi-3 kenaf (Hibiscus cannabinus L.) by pyrolysis-gas chromatography/mass spectrometry and cupric oxide oxidation. Ind Crops Prod 22(3):223-232. doi:10.1016/j.indcrop.2005.01.002

43. Lopes FF, Silverio FO, Baffa DCF, Loureiro ME, Barbosa MHP (2011) Determination of sugarcane bagasse lignin $\mathrm{S} / \mathrm{G} / \mathrm{H}$ ratio by pyrolysis GC/MS. J Wood Chem Technol 31(4):309-323. doi:10. 1080/02773813.2010.550379

44. Meier D, Faix O (1992) Pyrolysis-gas chromatography-mass spectrometry [of lignin in solid state]. In: Lin SY, Dence CW (eds) Methods in lignin chemistry. Springer, Berlin, pp 177-199

45. Rutkowski P (2012) Chemical composition of bio-oil produced by co-pyrolysis of biopolymer/polypropylene mixtures with $\mathrm{K}_{2} \mathrm{CO}_{3}$ and $\mathrm{ZnCl}_{2}$ addition. J Anal Appl Pyrolysis 95:38-47. doi:10.1016/ j.jaap.2012.01.003

46. Sonoda T, Ona T, Yokoi H, Ishida Y, Ohtani H, Tsuge S (2001) Quantitative analysis of detailed lignin monomer composition by pyrolysis-gas chromatography combined with preliminary acetylation of the samples. Anal Chem 73(22):5429-5435. doi:10. $1021 / \mathrm{ac} 010557 \mathrm{c}$

47. Sykes R, Yung M, Novaes E, Kirst M, Peter G, Davis M (2009) High-throughput screening of plant cell-wall composition using pyrolysis molecular beam mass spectroscopy. Biofuels Methods Mol Biol 581:169-183

48. Tuskan G, West D, Bradshaw HD, Neale D, Sewell M, Wheeler N, Megraw B, Jech K, Wiselogel A, Evans R, Elam C, Davis M, Dinus R (1999) Two high-throughput techniques for determining wood properties as part of a molecular genetics analysis of hybrid poplar and loblolly pine. Appl Biochem Biotechnol 77-79:55-65. doi:10. 1385/abab:77:1-3:55, Twentieth Symposium on Biotechnology for Fuels and Chemicals, 1998

49. Alves A, Schwanninger M, Pereira H, Rodrigues J (2006) Analytical pyrolysis as a direct method to determine the lignin content in wood. $\mathrm{J}$ Anal Appl Pyrolysis 76(1-2):209-213. doi:10.1016/j.jaap.2005.11. 004

50. Agblevor FA, Evans RJ, Johnson KD (1994) Molecular-beam mass-spectrometric analysis of lignocellulosic materials. I. Herbaceous biomass. J Anal Appl Pyrolysis 30(2):125-144. doi:10.1016/0165-2370(94)00808-6

51. del Rio JC, Gutierrez A, Rodriguez IM, Ibarra D, Martinez AT (2007) Composition of non-woody plant lignins and cinnamic acids by Py-GC/MS, Py/TMAH and FT-IR. J Anal Appl Pyrolysis 79(1-2):39-46. doi:10.1016/j.jaap.2006.09.003

52. Cozzani V, Lucchesi A, Stoppato G, Maschio G (1997) A new method to determine the composition of biomass by thermogravimetric analysis. Can J Chem Eng 75(1):127-133. doi:10.1002/cjce.5450750120

53. Freda C, Zimbardi F, Nanna F, Viola E (2012) Mathematical tool from corn stover TGA to determine its composition. Appl Biochem Biotechnol 167(8):2283-2294. doi:10.1007/s12010-012-9756-y

54. Serapiglia MJ, Cameron KD, Stipanovic AJ, Smart LB (2008) High-resolution thermogravimetric analysis for rapid characterization of biomass composition and selection of shrub willow varieties. Appl Biochem Biotechnol 145(1-3):3-11. doi:10.1007/s12010007-8061-7

55. Atalla RH, VanderHart DL (1999) The role of solid-state carbon13 NMR spectroscopy in studies of the nature of native celluloses. Solid State Nucl Magn Reson 15(1):1-19. doi:10.1016/s09262040(99)00042-9

56. Balakshin MY, Capanema EA, Chen C-L, Gracz HS (2003) Elucidation of the structures of residual and dissolved pine kraft lignins using an HMQC NMR technique. J Agric Food Chem 51(21):6116-6127. doi:10.1021/jf034372d

57. Bardet M, Gerbaud G, Giffard M, Doan C, Hediger S, Pape LL (2009) 13C high-resolution solid-state NMR for structural elucidation of archaeological woods. Prog Nucl Magn Reson Spectrosc 55(3):199-214. doi:10.1016/j.pnmrs.2009.02.001

58. Bunzel M, Ralph J (2006) NMR characterization of lignins isolated from fruit and vegetable insoluble dietary fiber. J Agric Food Chem 54(21):8352-8361. doi:10.1021/jf061525z

59. Capanema EA, Balakshin MY, Kadla JF (2004) A comprehensive approach for quantitative lignin characterization by NMR spectroscopy. J Agric Food Chem 52(7):1850-1860. doi:10.1021/jf035282b 
60. Capanema EA, Balakshin MY, Kadla JF (2005) Quantitative characterization of a hardwood milled wood lignin by nuclear magnetic resonance spectroscopy. J Agric Food Chem 53(25):9639-9649. doi:10.1021/jf0515330

61. Casas A, Oliet M, Alonso MV, Rodriguez F (2012) Dissolution of Pinus radiata and Eucalyptus globulus woods in ionic liquids under microwave radiation: lignin regeneration and characterization. Sep Purif Technol 97:115-122. doi:10.1016/j.seppur.2011.12.032

62. Çetinköl OP, Dibble DC, Cheng G, Kent MS, Knierim B, Auer M, Wemmer DE, Pelton JG, Melnichenko YB, Ralph J, Simmons BA, Holmes BM (2010) Understanding the impact of ionic liquid pretreatment on eucalyptus. Biofuels 1(1):33-46. doi:10.4155/bfs.09.5

63. Çetinköl OP, Smith-Moritz AM, Cheng G, Lao J, George A, Hong K, Henry R, Simmons BA, Heazlewood JL, Holmes BM (2012) Structural and chemical characterization of hardwood from tree species with applications as bioenergy feedstocks. PLoS One 7(12):e52820. doi:10.1371/journal.pone.0052820

64. del Rio JC, Rencoret J, Prinsen P, Martinez AT, Ralph J, Gutierrez A (2012) Structural characterization of wheat straw lignin as revealed by analytical pyrolysis, 2D-NMR, and reductive cleavage methods. J Agric Food Chem 60(23):5922-5935. doi:10. $1021 / \mathrm{jf} 301002 \mathrm{n}$

65. Fox SC, McDonald AG (2010) Chemical and thermal characterization of three industrial lignins and their corresponding lignin esters. BioResources 5(2):990-1009

66. Hall M, Bansal P, Lee JH, Realff MJ, Bommarius AS (2010) Cellulose crystallinity - a key predictor of the enzymatic hydrolysis rate. FEBS J 277(6):1571-1582. doi:10.1111/j.1742-4658. 2010.07585.x

67. Hoareau W, Trindade WG, Siegmund B, Castellan A, Frollini E (2004) Sugar cane bagasse and curaua lignins oxidized by chlorine dioxide and reacted with furfuryl alcohol: characterization and stability. Polym Degrad Stab 86(3):567-576. doi:10.1016/j. polymdegradstab.2004.07.005

68. Hori K, Meshitsuka G (2000) Structural heterogeneity of hardwood lignin: characteristics of end-wise lignin fraction. ACS Symp Ser 742:172-185. doi:10.1021/bk-2000-0742.ch006 (Lignin: Historical, Biological, and Materials Perspectives, 2000)

69. Huang F, Singh PM, Ragauskas AJ (2011) Characterization of milled wood lignin (MWL) in loblolly pine stem wood, residue, and bark. J Agric Food Chem 59(24):12910-12916. doi:10.1021/ jf202701b

70. Jääskeläinen AS, Sun Y, Argyropoulos DS, Tamminen T, Hortling B (2003) The effect of isolation method on the chemical structure of residual lignin. Wood Sci Technol 37(2):91-102. doi:10.1007/ s00226-003-0163-y

71. Katahira R, Sluiter JB, Schell DJ, Davis MF (2013) Degradation of carbohydrates during dilute sulfuric acid pretreatment can interfere with lignin measurements in solid residues. J Agric Food Chem 61(13):3286-3292. doi:10.1021/jf303727t

72. Li H, Foston MB, Kumar R, Samuel R, Gao X, Hu F, Ragauskas AJ, Wyman CE (2012) Chemical composition and characterization of cellulose for Agave as a fast-growing, drought-tolerant biofuels feedstock. RSC Adv 2(11):4951-4958. doi:10.1039/ c2ra20557b

73. Lupoi JS, Smith EA (2012) Characterization of woody and herbaceous biomasses lignin composition with $1064 \mathrm{~nm}$ dispersive multichannel Raman spectroscopy. Appl Spectrosc 66(8):903910. doi:10.1366/12-06621

74. Marita JM, Ralph J, Hatfield RD, Chapple C (1999) NMR characterization of lignins in Arabidopsis altered in the activity of ferulate 5-hydroxylase. Proc Natl Acad Sci U S A 96(22):12328-12332. doi:10.1073/pnas.96.22.12328

75. Marita JM, Vermerris W, Ralph J, Hatfield RD (2003) Variations in the cell wall composition of maize brown midrib mutants. $\mathrm{J}$ Agric Food Chem 51(5):1313-1321. doi:10.1021/jf0260592
76. Maunu SL (2002) NMR studies of wood and wood products. Prog Nucl Magn Reson Spectrosc 40(2):151-174. doi:10.1016/s00796565(01)00041-3

77. Newman RH (2004) Homogeneity in cellulose crystallinity between samples of Pinus radiata wood. Holzforschung 58(1):9196. doi:10.1515/hf.2004.012

78. Nuopponen MH, Wikberg HI, Birch GM, Jääskeläinen A-S, Maunu SL, Vuorinen T, Stewart D (2006) Characterization of 25 tropical hardwoods with Fourier transform infrared, ultraviolet resonance Raman, and 13C-NMR cross-polarization/magic-angle spinning spectroscopy. J Appl Polym Sci 102(1):810-819. doi:10. 1002/app.24143

79. Park S, Baker JO, Himmel ME, Parilla PA, Johnson DK (2010) Cellulose crystallinity index: measurement techniques and their impact on interpreting cellulase performance. Biotechnol Biofuels 3: 10 doi:10.1186/1754-6834-3-10

80. Ralph J, Landucci LL (2010) NMR of lignins. In: Heitner C, Dimmel DR, Schmidt JA (eds) Lignin and lignans: advances in chemistry. CRC, Boca Raton, pp 137-244

81. Ralph J (2010) Hydroxycinnamates in lignification. Phytochem Rev 9(1):65-83. doi:10.1007/s11101-009-9141-9

82. Ralph J, Hatfield RD, Piquemal J, Yahiaoui N, Pean M, Lapierre C, Boudet AM (1998) NMR characterization of altered lignins extracted from tobacco plants down-regulated for lignification enzymes cinnamyl-alcohol dehydrogenase and cinnamoyl-CoA reductase. Proc Natl Acad Sci U S A 95(22):12803-12808. doi:10.1073/pnas.95.22.12803

83. Rencoret J, Gutierrez A, Nieto L, Jimenez-Barbero J, Faulds CB, Kim H, Ralph J, Martinez AT, del Rio JC (2011) Lignin composition and structure in young versus adult Eucalyptus globulus plants. Plant Physiol 155(2):667-682. doi:10.1104/pp. 110.167254

84. Rencoret J, Marques G, Gutierrez A, Ibarra D, Li J, Gellerstedt G, Santos JI, Jimenez-Barbero J, Martinez AT, del Rio JC (2008) Structural characterization of milled wood lignins from different eucalypt species. Holzforschung 62(5):514-526. doi:10.1515/hf. 2008.096

85. Rencoret J, Ralph J, Marques G, Gutierrez A, Martinez AT, del Rio JC (2013) Structural characterization of lignin isolated from coconut (Cocos nucifera) coir fibers. J Agric Food Chem 61(10):2434-2445. doi:10.1021/jf304686x

86. Samuel R, Pu Y, Raman B, Ragauskas AJ (2010) Structural characterization and comparison of switchgrass ball-milled lignin before and after dilute acid pretreatment. Appl Biochem Biotechnol 162(1):62-74. doi:10.1007/s12010-009-8749-y

87. Santos RB, Capanema EA, Balakshin MY, Chang H-m, Jameel H (2012) Lignin structural variation in hardwood species. J Agric Food Chem 60(19):4923-4930. doi:10.1021/jf301276a

88. Sathitsuksanoh N, Zhu Z, Wi S, Percival Zhang YH (2011) Cellulose solvent-based biomass pretreatment breaks highly ordered hydrogen bonds in cellulose fibers of switchgrass. Biotechnol Bioeng 108 (3):521-529. doi:10.1002/bit.22964

89. Sun R, Tomkinson J, Wang S, Zhu W (1999) Characterization of lignins from wheat straw by alkaline peroxide treatment. Polym Degrad Stab 67(1):101-107. doi:10.1016/s0141-3910 (99)00099-3

90. Sun XF, Xu F, Sun RC, Wang YX, Fowler P, Baird MS (2004) Characteristics of degraded lignins obtained from steam exploded wheat straw. Polym Degrad Stab 86(2):245-256. doi:10.1016/j. polymdegradstab.2004.05.003

91. Thygesen A, Oddershede J, Lilholt H, Thomsen AB, Stahl K (2005) On the determination of crystallinity and cellulose content in plant fibres. Cellulose (Dordrecht Neth) 12(6):563-576. doi:10. 1007/s10570-005-9001-8

92. Yan J, Hu Z, Pu Y, Charles Brummer E, Ragauskas AJ (2010) Chemical compositions of four switchgrass populations. Biomass Bioenergy 34(1):48-53. doi:10.1016/j.biombioe.2009.09.010 
93. Martin-Sampedro R, Capanema EA, Hoeger I, Villar JC, Rojas OJ (2011) Lignin changes after steam explosion and laccase-mediator treatment of eucalyptus wood chips. J Agric Food Chem 59(16): 8761-8769. doi:10.1021/jf201605f

94. Pinto PC, Evtuguin DV, Pascoal Neto C (2005) Effect of structural features of wood biopolymers on hardwood pulping and bleaching performance. Ind Eng Chem Res 44(26):9777-9784. doi:10.1021/ ie 050760 o

95. Guerra A, Filpponen I, Lucia LA, Argyropoulos DS (2006) Comparative evaluation of three lignin isolation protocols for various wood species. J Agric Food Chem 54(26):9696-9705. doi:10.1021/jf062433c

96. Pinto PC, Evtuguin DV, Pascoal Neto C (2005) Chemical composition and structural features of the macromolecular components of plantation Acacia mangium wood. J Agric Food Chem 53(20):7856-7862. doi:10.1021/jf058081b

97. Chundawat SPS, Donohoe BS, Sousa LC, Elder T, Agarwal UP, Lu F, Ralph J, Himmel ME, Balan V, Dale BE (2011) Multi-scale visualization and characterization of lignocellulosic plant cell wall deconstruction during thermochemical pretreatment. Energy Environ Sci 4(3):973-984. doi:10.1039/c0ee00574f

98. del Rio JC, Prinsen P, Rencoret J, Nieto L, Jimenez-Barbero J, Ralph J, Martinez AT, Gutierrez A (2012) Structural characterization of the lignin in the cortex and pith of elephant grass (Pennisetum purpureum) stems. J Agric Food Chem 60(14):36193634. doi:10.1021/jf300099g

99. Hedenström M, Wiklund-Lindstroem S, Oeman T, Lu F, Gerber L, Schatz P, Sundberg B, Ralph J (2009) Identification of lignin and polysaccharide modifications in Populus wood by chemometric analysis of 2D NMR spectra from dissolved cell walls. Mol Plant 2(5):933-942. doi:10.1093/mp/ssp047

100. Lu F, Ralph J (2003) Non-degradative dissolution and acetylation of ball-milled plant cell walls: high-resolution solution-state NMR. Plant J 35(4):535-544. doi:10.1046/j.1365-313X.2003.01817.x

101. Mansfield SD, Kim H, Lu F, Ralph J (2012) Whole plant cell wall characterization using solution-state 2D NMR. Nat Protoc 7(9):1579-1589. doi:10.1038/nprot.2012.064

102. Terashima N, Akiyama T, Ralph S, Evtuguin D, Pascoal Neto C, Parkas J, Paulsson M, Westermark U, Ralph J (2009) 2D-NMR (HSQC) difference spectra between specifically 13C-enriched and unenriched protolignin of Ginkgo biloba obtained in the solution state of whole cell wall material. Holzforschung 63(4):379-384. doi:10.1515/hf.2009.074

103. Yelle DJ, Kaparaju P, Hunt CG, Hirth K, Kim H, Ralph J, Felby C (2013) Two-dimensional NMR evidence for cleavage of lignin and xylan substituents in wheat straw through hydrothermal pretreatment and enzymatic hydrolysis. BioEnergy Res 6(1):211221. doi:10.1007/s12155-012-9247-6

104. Zhang A, Lu F, Sun R, Ralph J (2009) Ferulate-coniferyl alcohol cross-coupled products formed by radical coupling reactions. Planta 229(5):1099-1108. doi:10.1007/s00425-009-0894-6

105. Duckworth JH (1998) Spectroscopic quantitative analysis. In: Workman J, Springsteen A (eds) Applied spectroscopy: a compact reference for practitioner. Academic, Boston, pp. 93-163. doi:10. 1016/b978-012764070-9/50006-8

106. Lavine BK, Workman J (2013) Chemometrics. Anal Chem (Washington, DC, U S) 85(2):705-714. doi:10.1021/ac303193j

107. Shaver JM (2001) Chemometrics for Raman spectroscopy. In: Lewis IR, Edwards HG (eds) Handbook of Raman spectroscopy. Marcel Dekker, New York, pp 275-306

108. Workman JJ Jr (1996) Interpretive spectroscopy for near infrared. Appl Spectrosc Rev 31(3):251-320. doi:10.1080/ 05704929608000571

109. Workman JJ Jr (2008) NIR spectroscopy calibration basics. In: Burns DA, Ciurczak EW (eds) Handbook of near-infrared analysis, 3rd edn. CRC, Boca Raton, pp 123-150
110. Gao X, Kumar R, DeMartini JD, Li H, Wyman CE (2013) Application of high throughput pretreatment and co-hydrolysis system to thermochemical pretreatment. Part 1: dilute acid. Biotechnol Bioeng 110(3):754-762. doi:10.1002/bit.24751

111. Selig MJ, Tucker MP, Law C, Doeppke C, Himmel ME, Decker SR (2011) High throughput determination of glucan and xylan fractions in lignocelluloses. Biotechnol Lett 33(5):961-967. doi:10.1007/s10529-011-0526-7

112. Zavrel M, Bross D, Funke M, Buechs J, Spiess AC (2009) Highthroughput screening for ionic liquids dissolving (ligno-)cellulose. Bioresour Technol 100(9):2580-2587. doi:10.1016/j.biortech. 2008.11.052

113. Goldman DS (2000) Near-infrared spectroscopy in process analysis. In: Peterson JW (ed) Encyclopedia of analytical chemistry-process instrumental methods, vol 9. Wiley, New York, pp 8256-8264

114. Jehlicka J, Vitek P, Edwards HGM, Hargreaves M, Capoun T (2009) Rapid outdoor non-destructive detection of organic minerals using a portable Raman spectrometer. J Raman Spectrosc 40(11):1645-1651. doi:10.1002/jrs.2313

115. Jehlicka J, Vitek P, Edwards HGM, Heagraves M, Capoun T (2009) Application of portable Raman instruments for fast and non-destructive detection of minerals on outcrops. Spectrochim Acta, Part A 73A(3):410-419. doi:10.1016/j.saa.2008.09.004

116. Jimare BMT, Bosch OC, Sanchez RF (2008) Process analytical chemistry: applications of near infrared spectrometry in environmental and food analysis: an overview. Appl Spectrosc Rev 43(5):452-484. doi:10.1080/05704920802031382

117. Lewis IR (2001) Process Raman spectroscopy. In: Lewis IR, Edwards HG (eds) Handbook of Raman spectroscopy. Marcel Dekker, New York, pp 919-973

118. Vitek P, Ali EMA, Edwards HGM, Jehlicka J, Cox R, Page K (2012) Evaluation of portable Raman spectrometer with $1064 \mathrm{~nm}$ excitation for geological and forensic applications. Spectrochim Acta Part A 86:320-327. doi:10.1016/j.saa.2011.10.043

119. Agarwal UP, Atalla RH (2010) Vibrational spectroscopy. In: Heitner C, Dimmel DR, Schmidt JA (eds) Lignin and lignans: advances in chemistry. CRC, Boca Raton, pp 103-136

120. Coates J (2000) Interpretation of infrared spectra, a practical approach. In: Meyers RA (ed) Encyclopedia of analytical chemistry. Wiley, Chichester, pp 10815-10837

121. Dao NQ (2006) Dispersive Raman spectroscopy, current instrumental designs. In: Meyers RA (ed) Encyclopedia of analytical chemistry. Wiley, Hoboken, pp 13024-13058

122. DeThomas FA, Brimmer PJ (2002) Monochromators for near-infrared spectroscopy. In: Chalmers JM, Griffiths PR (eds) Handbook of vibrational spectroscopy, vol 1. Wiley, Chichester, pp 383-392

123. Edwards HGM (2006) Fourier transform Raman instrumentation. In: Meyers RA (ed) Encyclopedia of analytical chemistry. Wiley, Hoboken, pp 13058-13078

124. McCreery RL (2000) Raman spectroscopy for chemical analysis. Wiley, New York, p 448

125. Schmidt JA (2010) Electronic spectroscopy of lignins. In: Heitner C, Dimmel DR, Schmidt JA (eds) Lignin and lignans: advances in chemistry. CRC, Boca Raton, pp 49-102

126. Skoog DA, Holler FJ, Nieman TA (1998) Principles of instrumental analysis, 5th edn. Harcourt, Brace, \& Company, Philadelphia

127. Smith ME, Webb GA (2000) Solid state NMR. Nucl Magn Reson 29:251-315. doi:10.1039/9781847553850-00251

128. Smith W, Dent G (2005) Modern Raman spectroscopy. Wiley, Chichester

129. Stark EW (2002) Near-Infrared array spectrometers. In: Chalmers JM, Griffiths PR (eds) Handbook of vibrational spectroscopy, vol 1. Wiley, Chichester, pp 393-422

130. Workman J, Lavine B, Chrisman R, Koch M (2011) Process analytical chemistry. Anal Chem (Washington DC US) 83(12):45574578. doi:10.1021/ac200974w 
131. Workman JJ Jr (2001) Infrared and Raman spectroscopy in paper and pulp analysis. Appl Spectrosc Rev 36(2 \& 3):139-168. doi:10.1081/asr-100106154

132. Agarwal UP (1999) An overview of Raman spectroscopy as applied to lignocellulosic materials. In: Argyropoulos DS (ed) Advances in lignocellulosic characterization. TAPPI, Atlanta, pp 201-225

133. Agarwal UP (2008) Raman spectroscopic characterization of wood and pulp fibers. In: Hu TQ (ed) Charactization of lignocellulose materials. Blackwell, Oxford, pp 17-35. doi:10.1002/ 9781444305425.ch2

134. Agarwal UP (2011) Lignin quantitation by FT-Raman spectroscopy. In: Proceedings 16th international symposium on wood, fiber and pulping chemistry, Tianjin, China, June 8-10, 2011. pp 170173

135. Agarwal UP, Atalla RH (1995) FT Raman spectroscopy: what it is and what it can do for research on lignocellulosic materials. Int Symp Wood Pulping Chem 8th 3:67-72

136. Agarwal UP, Kawai N (2005) "Self-absorption" phenomenon in near-infrared Fourier transform Raman spectroscopy of cellulosic and lignocellulosic materials. Appl Spectrosc 59(3):385-388. doi:10.1366/0003702053585327

137. Agarwal UP, McSweeny JD, Ralph SA (2011) FT-Raman investigation of milled-wood lignins: softwood, hardwood, and chemically modified black spruce lignins. J Wood Chem Technol 31(4):324-344. doi:10.1080/02773813.2011.562338

138. Agarwal UP, Ralph SA (1997) FT-Raman spectroscopy of wood: identifying contributions of lignin and carbohydrate polymers in the spectrum of black spruce (Picea mariana). Appl Spectrosc 51(11):1648-1655. doi:10.1366/0003702971939316

139. Agarwal UP, Ralph SA (2008) Determination of ethylenic residues in wood and TMP of spruce by FT-Raman spectroscopy. Holzforschung 62(6):667-675. doi:10.1515/hf.2008.112

140. Agarwal UP, Reiner RR, Ralph SA (2013) Estimation of cellulose crystallinity of lignocelluloses using near-IR FT-Raman spectroscopy and comparison of the Raman and segal-WAXS methods. J Agric Food Chem 61(1):103-113. doi:10.1021/jf304465k

141. Agarwal UP, Reiner RS (2009) Near-IR surface-enhanced Raman spectrum of lignin. J Raman Spectrosc 40(11):1527-1534. doi:10. $1002 / j r s .2294$

142. Agarwal UP, Reiner RS, Ralph SA (2010) Cellulose I crystallinity determination using FT-Raman spectroscopy: univariate and multivariate methods. Cellulose (Dordrecht Neth) 17(4):721-733. doi: 10.1007/s10570-010-9420-z

143. Agarwal UP, Weinstock IA, Atalla RH (2003) FT-Raman spectroscopy for direct measurement of lignin concentrations in kraft pulps. Tappi J 2(1):22-26

144. Cao Y, Lu Y, Huang Y (2004) NIR FT-Raman study of biomass (Triticum aestivum) treated with cellulase. J Mol Struct 693(13):87-93. doi:10.1016/j.molstruc.2004.02.017

145. Káčuriková M, Wellner N, Ebringerová A, Hromádková Z, Wilson RH, Belton PS (1998) Characterization of xylan-type polysaccharides and associated cell wall components by FT-IR and FT-Raman spectroscopies. Food Hydrocolloids 13(1):35-41

146. Larsen KL, Barsberg S (2010) Theoretical and Raman spectroscopic studies of phenolic lignin model monomers. J Phys Chem B 114(23):8009-8021. doi:10.1021/jp1028239

147. Lavine BK, Davidson CE, Moores AJ, Griffiths PR (2001) Raman spectroscopy and genetic algorithms for the classification of wood types. Appl Spectrosc 55(8):960-966. doi:10. 1366/0003702011953108

148. Ona T, Sonoda T, Ito K, Shibata M, Katayama T, Kato T, Ootake Y (1998) Non-destructive determination of lignin syringyl/guaiacyl monomeric composition in native wood by Fourier transform Raman spectroscopy. J Wood Chem Technol 18(1):43-51. doi:10. $1080 / 02773819809350124$
149. Ona T, Sonoda T, Ito K, Shibata M, Kato T, Otake Y (1997) Nondestructive determination of wood constituents by Fouriertransform Raman spectroscopy. J Wood Chem Technol 17(4): 399-417. doi:10.1080/02773819708003141

150. Ona T, Sonoda T, Ito K, Shibata M, Kato T, Ootake Y (1998) Non-destructive determination of hemicellulosic neutral sugar composition in native wood by Fourier transform Raman spectroscopy. J Wood Chem Technol 18(1):27-41. doi:10.1080/ 02773819809350123

151. Ona T, Sonoda T, Ito K, Shibata M, Kato T, Ootake Y (1998) Determination of wood basic density by Fourier transform Raman spectroscopy. J Wood Chem Technol 18(3):367-379. doi:10. 1080/02773819809349586

152. Ona T, Sonoda T, Ito K, Shibata M, Kato T, Ootake Y, Tamai Y, Kojima Y (2000) Rapid prediction of native wood pulp properties by Fourier-transform Raman spectroscopy. J Pulp Pap Sci 26(2):43-47

153. Ona T, Sonoda T, Ohshima J, Yokota S, Yoshizawa N (2003) A rapid quantitative method to assess eucalyptus wood properties for kraft pulp production by FT-Raman spectroscopy. J Pulp Pap Sci 29(1):6-10

154. Proniewicz LM, Paluszkiewicz C, Weselucha-Birczynska A, Baranski A, Dutka D (2002) FT-IR and FT-Raman study of hydrothermally degraded groundwood-containing paper. J Mol Struct 614(1-3):345-353. doi:10.1016/s0022-2860(02)00275-2

155. Schenzel K, Almloef H, Germgard U (2009) Quantitative analysis of the transformation process of cellulose I $\rightarrow$ cellulose II using NIR FT Raman spectroscopy and chemometric methods. Cellulose (Dordrecht Neth) 16(3):407-415. doi:10.1007/s10570-009-9286-0

156. Schenzel K, Fischer S (2001) NIR FT Raman spectroscopy-a rapid analytical tool for detecting the transformation of cellulose polymorphs. Cellulose (Dordrecht Neth) 8(1):49-57

157. Schenzel K, Fischer S, Brendler E (2005) New method for determining the degree of cellulose I crystallinity by means of FT Raman spectroscopy. Cellulose (Dordrecht Neth) 12(3):223231. doi:10.1007/s10570-004-3885-6

158. Schulz H, Baranska M (2007) Identification and quantification of valuable plant substances by IR and Raman spectroscopy. Vib Spectrosc 43(1):13-25. doi:10.1016/j.vibspec.2006.06.001

159. Sene CFB, McCann MC, Wilson RH, Grinter R (1994) Fouriertransform Raman and Fourier-transform infrared spectroscopy. An investigation of five higher plant cell walls and their components. Plant Physiol 106(4):1623-1631

160. Sivakesava S, Irudayaraj J, Demirci A (2001) Monitoring a bioprocess for ethanol production using FT-MIR and FT-Raman spectroscopy. J Ind Microbiol Biotechnol 26(4):185-190. doi:10. 1038/sj.jim.7000124

161. Sun L, Varanasi P, Yang F, Loque D, Simmons BA, Singh S (2012) Rapid determination of syringyl:guaiacyl ratios using FTRaman spectroscopy. Biotechnol Bioeng 109(3):647-656. doi:10. 1002/bit.24348

162. Takayama M, Johjima T, Yamanaka T, Wariishi H, Tanaka H (1997) Fourier-transform Raman assignment of guaiacyl and syringyl marker bands for lignin determination. Spectrochim Acta Part A 53A(10):1621-1628. doi:10.1016/s1386-1425(97)00100-5

163. Vester J, Felby C, Nielsen OF, Barsberg S (2004) Fourier transform Raman difference spectroscopy for detection of lignin oxidation products in thermomechanical pulp. Appl Spectrosc 58(4):404-409. doi:10.1366/000370204773580239

164. Kihara M, Takayama M, Wariishi H, Tanaka H (2002) Determination of the carbonyl groups in native lignin utilizing Fourier transform Raman spectroscopy. Spectrochim Acta Part A 58A(10):2213-2221. doi:10.1016/s1386-1425(01)00693-x

165. Gollapalli LE, Dale BE, Rivers DM (2002) Predicting digestibility of ammonia fiber explosion (AFEX)-treated rice straw. Appl Biochem Biotechnol 98-100:23-35. doi:10.1385/abab:98-100:19:23 
166. Yoshida M, Liu Y, Uchida S, Kawarada K, Ukagami Y, Ichinose H, Kaneko S, Fukuda K (2008) Effects of cellulose crystallinity, hemicellulose, and lignin on the enzymatic hydrolysis of Miscanthus sinensis to monosaccharides. Biosci Biotechnol Biochem 72 (3):805-810. doi:10.1271/bbb.70689

167. Obst JR, Landucci LL (1986) The syringyl content of softwood lignin. J Wood Chem Technol 6(3):311-327. doi:10.1080/ 02773818608085230

168. Tsutsumi Y, Kondo R, Sakai K, Imamura H (1995) The difference of reactivity between syringyl lignin and guaiacyl lignin in alkaline systems. Holzforschung 49(5):423-428. doi:10.1515/hfsg. 1995.49.5.423

169. Browning BL (1963) Wood lignins. In: Browning BL (ed) The chemistry of wood. Interscience, New York, pp 249-311

170. Sarkanen KV, Hergert HL (1971) Classification and distribution. In: Sarkanen KV, Ludwig CH (eds) Lignins: occurrence and formation, structure, chemical and macromolecular properties, and utilization. Wiley, New York, pp 43-94

171. Meyer MW, Lupoi JS, Smith EA (2011) 1064 nm dispersive multichannel Raman spectroscopy for the analysis of plant lignin. Anal Chim Acta 706(1):164-170. doi:10.1016/j.aca.2011.08.031

172. Shih C-J, Lupoi JS, Smith EA (2011) Raman spectroscopy measurements of glucose and xylose in hydrolysate: role of corn stover pretreatment and enzyme composition. Bioresour Technol 102(8):5169-5176. doi:10.1016/j.biortech.2011.01.043

173. Shih C-J, Smith EA (2009) Determination of glucose and ethanol after enzymatic hydrolysis and fermentation of biomass using Raman spectroscopy. Anal Chim Acta 653(2):200-206. doi:10. 1016/j.aca.2009.09.012

174. Li C, Sun L, Simmons BA, Singh S (2013) Comparing the recalcitrance of eucalyptus, pine, and switchgrass using ionic liquid and dilute acid pretreatments. BioEnergy Res 6(1):14-23. doi:10.1007/s12155-012-9220-4

175. Li C, Cheng G, Balan V, Kent MS, Ong M, Chundawat SPS, Sousa L, Melnichenko YB, Dale BE, Simmons BA, Singh S (2011) Influence of physico-chemical changes on enzymatic digestibility of ionic liquid and AFEX pretreated corn stover. Bioresour Technol 102(13):6928-6936. doi:10.1016/j.biortech.2011.04.005

176. Li C, Knierim B, Manisseri C, Arora R, Scheller HV, Auer M, Vogel KP, Simmons BA, Singh S (2010) Comparison of dilute acid and ionic liquid pretreatment of switchgrass: biomass recalcitrance, delignification and enzymatic saccharification. Bioresour Technol 101(13):4900-4906. doi:10.1016/j.biortech.2009.10.066

177. Röder T, Sixta H (2005) Confocal Raman spectroscopyapplications on wood, pulp, and cellulose fibres. Macromol Symp 223:57-66. doi:10.1002/masy.200550504

178. Barsberg S, Matousek P, Towrie M, Jørgensen H, Felby C (2006) Lignin radicals in the plant cell wall probed by Kerr-gated resonance Raman spectroscopy. Biophys J 90(8):2978-2986. doi:10. 1529/biophysj.105.070391

179. Barsberg S, Matousek P, Towrie M (2005) Structural analysis of lignin by resonance Raman spectroscopy. Macromol Biosci 5(8):743-752. doi:10.1002/mabi.200500042

180. Saariaho A-M, Jääskeläinen A-S, Matousek P, Towrie M, Parker AW, Vuorinen T (2004) Resonance Raman spectroscopy of highly fluorescing lignin containing chemical pulps: suppression of fluorescence with an optical Kerr gate. Holzforschung 58(1):82-90. doi: $10.1515 / \mathrm{hf} .2004 .011$

181. Jääskeläinen A-S, Saariaho A-M, Vyörykka J, Vuorinen T, Matousek P, Parker AW (2006) Application of UV-Vis and resonance Raman spectroscopy to study bleaching and photoyellowing of thermomechanical pulps. Holzforschung 60(3):231-238. doi:10. 1515/hf.2006.038

182. Saariaho A-M, Argyropoulos DS, Jääskeläinen A-S, Vuorinen T (2005) Development of the partial least squares models for the interpretation of the UV resonance Raman spectra of lignin model compounds. Vib Spectrose 37(1):111-121. doi:10.1016/j.vibspec. 2004.08.001

183. Saariaho A-M, Jääskeläinen A-S, Nuopponen M, Vuorinen T (2003) Ultraviolet resonance Raman spectroscopy in lignin analysis: determination of characteristic vibrations of $p$-hydroxyphenyl, guaiacyl, and syringyl lignin structures. Appl Spectrosc 57(1):5866. doi:10.1366/000370203321165214

184. Nuopponen M, Vuorinen T, Jaemsae S, Viitaniemi P (2004) Thermal modifications in softwood studied by FT-IR and UV resonance Raman spectroscopies. J Wood Chem Technol 24(1):13-26. doi:10. 1081/wct-120035941

185. Nuopponen M, Willfoer S, Jääskeläinen AS, Sundberg A, Vuorinen T (2004) A UV resonance Raman (UVRR) spectroscopic study on the extractable compounds of Scots pine (Pinus sylvestris) wood. Part I: lipophilic compounds. Spectrochim Acta Part A 60A(13):29532961. doi:10.1016/j.saa.2004.02.008

186. Nuopponen M, Willfor S, Jääskeläinen AS, Vuorinen T (2004) A UV resonance Raman (UVRR) spectroscopic study on the extractable compounds in Scots pine (Pinus sylvestris) wood. Part II. Hydrophilic compounds. Spectrochim Acta A Mol Biomol Spectrosc 60(13): 2963-2968

187. Mononen K, Jääskeläinen A-S, Alvila L, Pakkanen TT, Vuorinen T (2005) Chemical changes in silver birch (Betula pendula Roth) wood caused by hydrogen peroxide bleaching and monitored by color measurement (CIELab) and UV-vis, FTIR and UVRR spectroscopy. Holzforschung 59(4):381-388. doi:10.1515/hf.2005.063

188. Halttunen M, Vyörykka J, Hortling B, Tamminen T, Batchelder D, Zimmermann A, Vuorinen T (2001) Study of residual lignin in pulp by UV resonance Raman spectroscopy. Holzforschung 55(6):631-638. doi:10.1515/hf.2001.103

189. Pandey KK, Vuorinen T (2008) UV resonance Raman spectroscopic study of photodegradation of hardwood and softwood lignins by UV laser. Holzforschung 62(2):183-188. doi:10.1515/ hf.2008.046

190. Jääskeläinen A-S, Saariaho A-M, Vuorinen T (2005) Quantification of lignin and hexenuronic acid in bleached hardwood kraft pulps: a new calibration method for UVRR spectroscopy and evaluation of the conventional methods. J Wood Chem Technol 25(1-2):51-65. doi:10.1081/wct-200058239

191. Agarwal UP (2006) Raman imaging to investigate ultrastructure and composition of plant cell walls: distribution of lignin and cellulose in black spruce wood (Picea mariana). Planta 224(5):1141-1153. doi:10.1007/s00425-006-0295-z

192. Gierlinger N, Schwanninger M (2006) Chemical imaging of poplar wood cell walls by confocal Raman microscopy. Plant Physiol 140(4):1246-1254. doi:10.1104/pp. 105.066993

193. Saar BG, Zeng Y, Freudiger CW, Liu Y-S, Himmel ME, Xie XS, Ding S-Y (2010) Label-free, real-time monitoring of biomass processing with stimulated Raman scattering microscopy. Angew Chem 122(32):5476-5479. doi:10.1002/anie.201000900

194. Sun L, Simmons BA, Singh S (2010) Understanding tissue specific compositions of bioenergy feedstocks through hyperspectral Raman imaging. Biotechnol Bioeng 108(2):286-295. doi:10. 1002/bit.22931

195. Sun L, Li C, Xue Z, Simmons BA, Singh S (2013) Unveiling highresolution, tissue specific dynamic changes in corn stover during ionic liquid pretreatment. RSC Adv 3(6):2017-2027. doi:10. 1039/c2ra20706k

196. Agarwal UP, Sabo R, Reiner RS, Clemons CM, Rudie AW (2012) Spatially resolved characterization of cellulose nanocrystalpolypropylene composite by confocal Raman microscopy. Appl Spectrosc 66(7):750-756. doi:10.1366/11-06563

197. Abdul Khalil HPS, Yusra AFI, Bhat AH, Jawaid M (2009) Cell wall ultrastructure, anatomy, lignin distribution, and chemical composition of Malaysian cultivated kenaf fiber. Ind Crops Prod 31(1):113-121. doi:10.1016/j.indcrop.2009.09.008 
198. Adapa PK, Tabil LG, Schoenau GJ, Canam T, Dumonceaux T (2011) Quantitative analysis of lignocellulosic components of non-treated and steam exploded barley, canola, oat and wheat straw using Fourier transform infrared spectroscopy. J Agric Sci Technol B 1(2):177-188

199. Allison GG, Morris C, Hodgson E, Jones J, Kubacki M, Barraclough T, Yates N, Shield I, Bridgwater AV, Donnison IS (2009) Measurement of key compositional parameters in two species of energy grass by Fourier transform infrared spectroscopy. Bioresour Technol 100(24):6428-6433. doi:10.1016/j.biortech. 2009.07.015

200. Alves AMM, Simoes RFS, Santos CA, Potts BM, Rodrigues J, Schwanninger M (2012) Determination of Eucalyptus globulus wood extractives content by near infrared-based partial least squares regression models: comparison between extraction procedures. J Near Infrared Spectrosc 20(2):275-285. doi:10.1255/ jnirs.987

201. Backa S, Brolin A, Nilsson T (2001) Characterization of fungal degraded birch wood by FTIR and Py-GC. Holzforschung 55(3):225-232. doi:10.1515/hf.2001.037

202. Bermello A, Del Valle M, Orea U, Carballo LR (2002) Characterization by infrared spectrometry of lignins of three Eucalyptus species. Int J Polym Mater 51(6):557-566. doi:10. 1080/00914030209696301

203. Biagini E, Barontini F, Tognotti L (2006) Devolatilization of biomass fuels and biomass components studied by TG/FTIR technique. Ind Eng Chem Res 45(13):4486-4493. doi:10.1021/ ie0514049

204. Djikanovic D, Kalauzi A, Radotic K, Lapierre C, Jeremic M (2007) Deconvolution of lignin fluorescence spectra: a contribution to the comparative structural studies of lignins. Russ J Phys Chem A 81(9):1425-1428. doi:10.1134/s0036024407090142

205. Irfan M, Syed Q, Abbas S, Sher MG, Baig S, Nadeem M (2011) FTIR and SEM analysis of thermo-chemical fractionated sugarcane bagasse. Turk Biyokim Derg 36(4):322-328

206. Jones RW, Meglen RR, Hames BR, McClelland JF (2002) Chemical analysis of wood chips in motion using thermal-emission midinfrared spectroscopy with projection to latent structures regression. Anal Chem 74(2):453-457. doi:10.1021/ac0106445

207. Kataoka Y, Kiguchi M (2001) Depth profiling of photo-induced degradation in wood by FT-IR microspectroscopy. J Wood Sci 47(4):325-327. doi:10.1007/bf00766722

208. Kline LM, Hayes DG, Womac AR, Labbe N (2010) Simplified determination of lignin content in hard and soft woods via UVspectrophotometric analysis of biomass dissolved in ionic liquids. BioResources 5(3):1366-1383

209. McCann MC, Defernez M, Urbanowicz BR, Tewari JC, Langewisch T, Olek A, Wells B, Wilson RH, Carpita NC (2007) Neural network analyses of infrared spectra for classifying cell wall architectures. Plant Physiol 143(3):1314-1326. doi:10.1104/ pp. 106.093054

210. Morrison WH III, Himmelsbach DS, Akin DE, Evans JD (2003) Chemical and spectroscopic analysis of lignin in isolated flax fibers. J Agric Food Chem 51(9):2565-2568. doi:10.1021/jf020885t

211. Tucker MP, Mitri RK, Eddy FP, Nguyen QA, Gedvilas LM, Webb JD (2000) Fourier transform infrared quantification of sugars in pretreated biomass liquors. Appl Biochem Biotechnol 84-86:3950. doi:10.1385/abab:84-86:1-9:39

212. White KE, Reeves JB III, Coale FJ (2011) Mid-infrared diffuse reflectance spectroscopy for the rapid analysis of plant root composition. Geoderma 167-168:197-203. doi:10.1016/j.geoderma.2011.08. 009

213. Yuen S-N, Choi S-M, Phillips DL, Ma C-Y (2009) Raman and FTIR spectroscopic study of carboxymethylated non-starch polysaccharides. Food Chem 114(3):1091-1098. doi:10.1016/j. foodchem.2008.10.053
214. Singh S, Simmons BA, Vogel KP (2009) Visualization of biomass solubilization and cellulose regeneration during ionic liquid pretreatment of switchgrass. Biotechnol Bioeng 104(1):68-75. doi:10.1002/bit.22386

215. Burns DA, Schultz, TP (2008) FT/IR vs. NIR: a study with lignocellulose. In: Burns DA, Ciurczak EW (eds) Handbook of near-infrared analysis, vol. 35. 3rd edn, CRC, Boca Raton, pp. 479-484

216. Owen NL, Thomas DW (1989) Infrared studies of "hard" and "soft" woods. Appl Spectrosc 43(3):451-455. doi:10.1366/ 0003702894202760

217. Bjarnestad S, Dahlman O (2002) Chemical compositions of hardwood and softwood pulps employing photoacoustic Fourier Transform infrared spectroscopy in combination with partial least-squares analysis. Anal Chem 74(22):5851-5858. doi:10. $1021 / \mathrm{ac} 025926 \mathrm{z}$

218. Meder R, Gallagher S, Mackie KL, Bohler H, Meglen RR (1999) Rapid determination of the chemical composition and density of Pinus radiata by PLS modeling of transmission and diffuse reflectance FTIR spectra. Holzforschung 53(3):261-266. doi:10.1515/ hf. 1999.044

219. Rodrigues J, Puls J, Faix O, Pereira H (2001) Determination of monosaccharide composition of Eucalyptus globulus wood by FTIR spectroscopy. Holzforschung 55(3):265-269. doi:10.1515/ hf. 2001.044

220. Akerholm M, Salmen L (2003) The oriented structure of lignin and its viscoelastic properties studied by static and dynamic FT-IR spectroscopy. Holzforschung 57(5):459-465. doi:10.1515/hf. 2003.069

221. Adler Paul R, Sanderson Matt A, Weimer Paul J, Vogel Kenneth P (2009) Plant species composition and biofuel yields of conservation grasslands. Ecol Appl 19(8):2202-2209

222. Alves A, Simoes R, Stackpole DJ, Vaillancourt RE, Potts BM, Schwanninger M, Rodrigues J (2011) Determination of the syringyl/guaiacyl ratio of Eucalyptus globulus wood lignin by near infrared-based partial least squares regression models using analytical pyrolysis as the reference method. J Near Infrared Spectrosc 19(5):343-348. doi:10.1255/jnirs. 946

223. Armenta S, Moros J, Garrigues S, De La Guardia M (2010) The use of near-infrared spectrometry in the olive oil industry. Crit Rev Food Sci Nutr 50(6):567-582. doi:10.1080/10408390802606790

224. Bailleres H, Davrieus F, Pichavant FH (2002) Near infrared analysis as a tool for rapid screening of some major wood characteristics in a eucalyptus breeding program. Ann For Sci 59(5-6):479490. doi:10.1051/Forest:20032

225. Blanco M, Peinado Antonio C, Mas J (2004) Analytical monitoring of alcoholic fermentation using NIR spectroscopy. Biotechnol Bioeng 88(4):536-542

226. Downes GM, Harwood CE, Wiedemann J, Ebdon N, Bond H, Meder R (2012) Radial variation in Kraft pulp yield and cellulose content in Eucalyptus globulus wood across three contrasting sites predicted by near infrared spectroscopy. Can J For Res 42(8):1577-1586. doi:10.1139/x2012-083

227. Hames BR, Thomas SR, Sluiter AD, Roth CJ, Templeton DW (2003) Rapid biomass analysis. New tools for compositional analysis of corn stover feedstocks and process intermediates from ethanol production. Appl Biochem Biotechnol 105-108:5-16. doi:10.1385/abab:105:1-3:5

228. Hatfield R, Fukushima RS (2005) Can lignin be accurately measured? Crop Sci 45(3):832-839. doi:10.2135/cropsci2004.0238

229. Hou S, Li L (2011) Rapid characterization of woody biomass digestibility and chemical composition using near-infrared spectroscopy. J Integr Plant Biol 53(2):166-175. doi:10.1111/j.17447909.2010.01003.x

230. Houghton TP, Stevens DM, Pryfogle PA, Wright CT, Radtke CW (2009) The effect of drying temperature on the composition of 
biomass. Appl Biochem Biotechnol 153(1-3):4-10. doi:10.1007/ s12010-008-8406-x

231. Jin S, Chen H (2007) Near-infrared analysis of the chemical composition of rice straw. Ind Crops Prod 26(2):207-211. doi:10.1016/j. indcrop.2007.03.004

232. Jones PD, Schimleck LR, Peter GF, Daniels RF, Clark A III (2006) Nondestructive estimation of wood chemical composition of sections of radial wood strips by diffuse reflectance near infrared spectroscopy. Wood Sci Technol 40(8):709-720. doi:10.1007/ s00226-006-0085-6

233. Labbe N, Ye XP, Franklin JA, Womac AR, Tyler DD, Rials TG (2008) Analysis of switchgrass characteristics using near infrared spectroscopy. BioResources 3(4):1329-1348

234. Lemus R, Brummer EC, Moore KJ, Molstad NE, Burras CL, Barker MF (2002) Biomass yield and quality of 20 switchgrass populations in southern Iowa, USA. Biomass Bioenergy 23(6):433-442. doi:10. 1016/s0961-9534(02)00073-9

235. Liu Y, Ying Y, Yu H, Fu X (2006) Comparison of the HPLC method and FT-NIR analysis for quantification of glucose, fructose, and sucrose in intact apple fruits. J Agric Food Chem 54(8):2810-2815

236. Nkansah K, Dawson-Andoh B (2010) Rapid characterization of biomass using fluorescence spectroscopy coupled with multivariate data analysis. I. Yellow poplar (Liriodendron tulipifera L.). J Renewable Sustainable Energy 2 (2):023103/023101-023103/ 023112. doi: $10.1063 / 1.3290749$

237. Nkansah K, Dawson-Andoh B (2010) Rapid characterization of biomass using fluorescence spectroscopy coupled with multivariate data analysis. II. Northern red oak (Quercus rubra). J Renewable Sustainable Energy 2 (4):043101/043101-043101/ 043110. doi: $10.1063 / 1.3404181$

238. Nousiainen J, Ahvenjarvi S, Rinne M, Hellamaki M, Huhtanen P (2004) Prediction of indigestible cell wall fraction of grass silage by near infrared reflectance spectroscopy. Anim Feed Sci Technol 115(3-4):295-311. doi:10.1016/j.anifeedsci. 2004.03.004

239. Nousiainen J, Rinne M, Hellaemaeki M, Huhtanen P (2003) Prediction of the digestibility of primary growth and regrowth grass silages from chemical composition, pepsin-cellulase solubility and indigestible cell wall content. Anim Feed Sci Technol 110(1-4):61-74. doi:10.1016/s0377-8401(03)00206-2

240. Poke FS, Raymond CA (2006) Predicting extractives, lignin, and cellulose contents using near infrared spectroscopy on solid wood in Eucalyptus globulus. J Wood Chem Technol 26(2):187-199. doi:10.1080/02773810600732708

241. Poke FS, Wright JK, Raymond CA (2004) Predicting extractives and lignin contents in Eucalyptus globulus using near infrared reflectance analysis. J Wood Chem Technol 24(1):55-67. doi:10.1081/wct120035944

242. Pordesimo LO, Hames BR, Sokhansanj S, Edens WC (2005) Variation in corn stover composition and energy content with crop maturity. Biomass Bioenergy 28(4):366-374. doi:10.1016/j.biombioe. 2004.09.003

243. Schimleck LR, Kube PD, Raymond CA (2004) Genetic improvement of kraft pulp yield in Eucalyptus nitens using cellulose content determined by near infrared spectroscopy. Can J For Res 34(11):2363-2370. doi:10.1139/x04-119

244. Schmer MR, Vogel KP, Mitchell RB, Dien BS, Jung HG, Casler MD (2012) Temporal and spatial variation in switchgrass biomass composition and theoretical ethanol yield. Agron J 104(1):54-64. doi:10.2134/agronj2011.0195

245. Smith-Moritz AM, Chern M, Lao J, Sze-To WH, Heazlewood JL, Ronald PC, Vega-Sanchez ME (2011) Combining multivariate analysis and monosaccharide composition modeling to identify plant cell wall variations by Fourier transform near infrared spectroscopy. Plant Methods 7:26. doi:10.1186/1746-4811-7-26
246. Stackpole Desmond J, Vaillancourt Rene E, Alves A, Rodrigues J, Potts Brad M (2011) Genetic variation in the chemical components of Eucalyptus globulus wood. G3 (Bethesda) 1(2):151-159

247. Templeton DW, Sluiter AD, Hayward TK, Hames BR, Thomas SR (2009) Assessing corn stover composition and sources of variability via NIRS. Cellulose (Dordrecht Neth) 16(4):621-639. doi:10.1007/s10570-009-9325-x

248. Tsuchikawa S (2007) A review of recent near infrared research for wood and paper. Appl Spectrosc Rev 42(1):43-71. doi:10.1080/ 05704920601036707

249. Wolfrum EJ, Sluiter AD (2009) Improved multivariate calibration models for corn stover feedstock and dilute-acid pretreated corn stover. Cellulose (Dordrecht Neth) 16(4):567-576. doi:10.1007/ s10570-009-9320-2

250. Yamada T, Yeh T-F, Chang H-M, Li L, Kadla JF, Chiang VL (2006) Rapid analysis of transgenic trees using transmittance near-infrared spectroscopy (NIR). Holzforschung 60(1):24-28. doi:10.1515/hf.2006.005

251. Ye XP, Liu L, Hayes D, Womac A, Hong K, Sokhansanj S (2008) Fast classification and compositional analysis of corn stover fractions using Fourier transform near-infrared techniques. Bioresour Technol 99(15):7323-7332. doi:10.1016/j.biortech.2007.12.063

252. Yeh T-F, Chang H-m, Kadla JF (2004) Rapid prediction of solid wood lignin content using transmittance near-infrared spectroscopy. J Agric Food Chem 52(6):1435-1439. doi:10.1021/jf034874r

253. Yeh T-F, Yamada T, Capanema E, Chang H-M, Chiang V, Kadla JF (2005) Rapid screening of wood chemical component variations using transmittance near-infrared spectroscopy. J Agric Food Chem 53(9):3328-3332. doi:10.1021/jf0480647

254. Blanco M, Villarroya I (2002) NIR spectroscopy: a rapid-response analytical tool. TrAC Trends Anal Chem 21(4):240-250. doi:10. 1016/s0165-9936(02)00404-1

255. Albinsson B, Li S, Lundquist K, Stomberg R (1999) The origin of lignin fluorescence. J Mol Struct 508(1-3):19-27. doi:10.1016/ s0022-2860(98)00913-2

256. Castellan A, Ruggiero R, Frollini E, Ramos LA, Chirat C (2007) Studies on fluorescence of cellulosics. Holzforschung 61(5):504 508. doi:10.1515/hf.2007.090

257. Liukko S, Tasapuro V, Liitia T (2007) Fluorescence spectroscopy for chromophore studies on bleached kraft pulps. Holzforschung 61(5):509-515. doi:10.1515/hf.2007.107

258. Machado AEH, Nicodem DE, Ruggiero R, Perez DS, Castellan A (2001) The use of fluorescent probes in the characterization of lignin: the distribution, by energy, of fluorophores in Eucalyptus grandis lignin. J Photochem Photobiol A 138(3):253-259. doi:10. 1016/s1010-6030(00)00413-5

259. Samorski M, Mueller-Newen G, Buechs J (2005) Quasi-continuous combined scattered light and fluorescence measurements: a novel measurement technique for shaken microtiter plates. Biotechnol Bioeng 92(1):61-68. doi:10.1002/bit.20573

260. Kensy F, Zang E, Faulhammer C, Tan R-K, Buechs J (2009) Validation of a high-throughput fermentation system based on online monitoring of biomass and fluorescence in continuously shaken microtiter plates. Microb Cell Fact 8:31. doi:10.1186/1475-2859-8-31

261. Kensy F, Engelbrecht C, Buechs J (2009) Scale-up from microtiter plate to laboratory fermenter: evaluation by online monitoring techniques of growth and protein expression in Escherichia coli and Hansenula polymorpha fermentations. Microb Cell Fact 8:68. doi:10.1186/1475-2859-8-68

262. Huber R, Ritter D, Hering T, Hillmer A-K, Kensy F, Mueller C, Wang L, Buechs J (2009) Robo-Lector - a novel platform for automated high-throughput cultivations in microtiter plates with high information content. Microb Cell Fact 8:42. doi:10.1186/ $1475-2859-8-42$

263. Masuko T, Minami A, Iwasaki N, Majima T, Nishimura S-I, Lee YC (2005) Carbohydrate analysis by a phenol-sulfuric acid 
method in microplate format. Anal Biochem 339(1):69-72. doi:10.1016/j.ab.2004.12.001

264. Van Soest PJ, Robertson JB, Lewis BA (1991) Methods for dietary fiber, neutral detergent fiber, and nonstarch polysaccharides in relation to animal nutrition. J Dairy Sci 74(10): 3583-3597

265. Updegraff DM (1969) Semimicro determination of cellulose in biological materials. Anal Biochem 32(3):420-424. doi:10.1016/ s0003-2697(69)80009-6

266. Nelson GH, Leming JA (1957) Evaluation of monoethanolamine method of cellulose determination for agricultural residues. Tappi 40:846-850

267. Dence CW (1992) The determination of lignin. In: Lin SY, Dence CW (eds) Methods in lignin chemistry. Springer, Berlin, pp 33-61

268. Lee SH, Doherty TV, Linhardt RJ, Dordick JS (2009) Ionic liquidmediated selective extraction of lignin from wood leading to enhanced enzymatic cellulose hydrolysis. Biotechnol Bioeng 102(5):1368-1376. doi:10.1002/bit.22179

269. Foster CE, Martin TM, Pauly M (2010) Comprehensive compositional analysis of plant cell walls (lignocellulosic biomass) part I: lignin. J Visualized Exp (37): e1745. doi:10.3791/1745

270. Lapierre C, Rolando C, Monties B (1983) Characterization of poplar lignins acidolysis products: capillary gas-liquid and liquidliquid chromatography of monomeric compounds. Holzforschung 37(4):189-198. doi:10.1515/hfsg.1983.37.4.189

271. Pepper JM, Baylis PET, Adler E (1959) Isolation and properties of lignins obtained by the acidolysis of spruce and aspen woods in dioxane-water medium. Can J Chem 37:1241-1248. doi:10.1139/ v59-183

272. Hedges JI, Ertel JR (1982) Characterization of lignin by gas capillary chromatography of cupric oxide oxidation products. Anal Chem 54(2):174-178. doi:10.1021/ac00239a007
273. Chen CL (1992) Determination of carbonyl groups [in lignin]. In: Lin SY, Dence CW (eds) Methods in lignin chemistry. Springer, Berlin, pp 446-457

274. Chen CL (1992) Determination of methoxyl groups [in lignin]. In: Lin SY, Dence CW (eds) Methods in lignin chemistry. Springer, Berlin, pp 465-472

275. Chen CL (1992) Determination of total and aliphatic hydroxyl groups [in lignin]. In: Lin SY, Dence CW (eds) Methods in lignin chemistry. Springer, Berlin, pp 409-422

276. Dence CW (1992) Determination of carboxyl groups [in lignin]. In: Lin SY, Dence CW (eds) Methods in lignin chemistry. Springer, Berlin, pp 458-464

277. Lai YZ (1992) Determination of phenolic hydroxyl groups [in lignin]. In: Lin SY, Dence CW (eds) Methods in lignin chemistry. Springer, Berlin, pp 423-434

278. Lygin AV, Upton J, Dohleman FG, Juvik J, Zabotina OA, Widholm JM, Lozovaya VV (2011) Composition of cell wall phenolics and polysaccharides of the potential bioenergy crop-Miscanthus. GCB Bioenergy 3(4):333-345. doi:10.1111/j.1757-1707.2011.01091.x

279. Bondar RJL, Mead DC (1974) Evaluation of glucose 6-phosphate dehydrogenase from Leuconostoc mesenteroides in the hexokinase method for determining glucose in serum. Clin Chem 20(5):586-590

280. Dolan JW, Snyder LR (2000) Gradient elution chromatography. In: Meyers RA (ed) Encyclopedia of analytical chemistry. Wiley, New York, pp 11342-11360

281. Dorsey JG (2000) Column theory and resolution in liquid chromatography. In: Meyers RA (ed) Encyclopedia of analytical chemistry. Wiley, New York, pp 11334-11342

282. Harris DC (2003) Gas chromatography. In: Quantitative chemical analysis. W.H. Freeman and Company, New York, pp 578-606

283. Lapierre C (2010) Determining lignin structure by chemical degradations. In: Heitner C, Dimmel DR, Schmidt JA (eds) Lignin and lignans: advances in chemistry. CRC, Boca Raton, pp 11-48 